Supporting Information

\title{
Dithiol-Dithione Tautomerism of 2,3-Pyrazinedithiol in the Synthesis of Copper and Silver Coordination Compounds
}

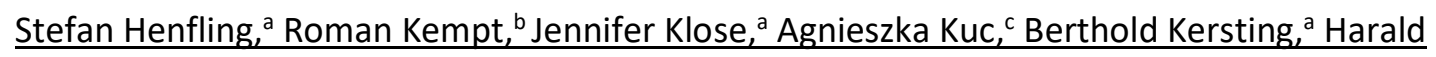
$\underline{\text { Krautscheid }^{\mathrm{a} *}}$

a) Institut für Anorganische Chemie, Universität Leipzig, Johannisallee 29, D-04103 Leipzig, Germany, Email: krautscheid@rz.uni-leipzig.de

b) Technische Universität Dresden, Professur für Theoretische Chemie, Bergstr. 66c, D-01062 Dresden, Germany

${ }^{c}$ Helmholtz-Zentrum Dresden-Rossendorf, Forschungsstelle Leipzig, Abteilung Reaktiver Transport, Institut für Ressourcenökologie, Permoserstr. 15, D-04318 Leipzig, Germany 


\section{Contents}

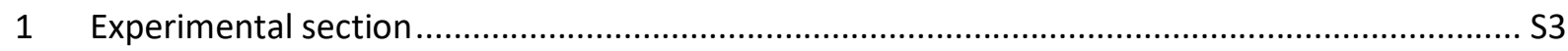

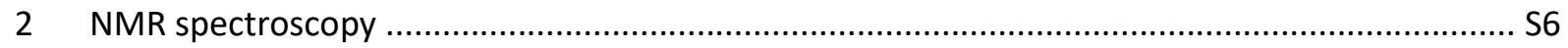

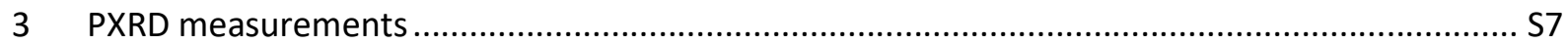

$4 \quad$ Temperature dependent PXRD measurements ................................................................... S8

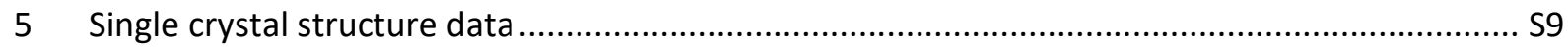

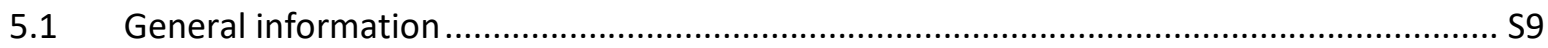

5.2 Selected bond lengths in $\left[\mathrm{Cu}\left(\mathrm{H}_{2} \mathrm{pdt}\right)_{2}\right] \mathrm{Cl}(\mathbf{1}),\left[\mathrm{Cu}(\mathrm{Hpdt})_{2}\right](\mathbf{3})$, and ${ }^{1 \mathrm{D}}\left[\mathrm{Cu}\left(\mathrm{H}_{2} \mathrm{pdt}\right) 1\right](\mathbf{4}) \ldots \ldots . . . \mathrm{S} 12$

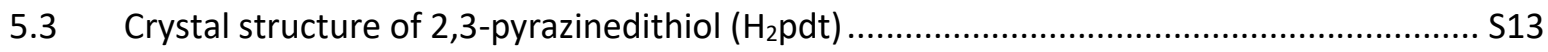

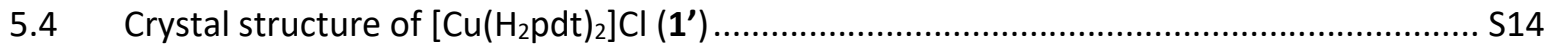

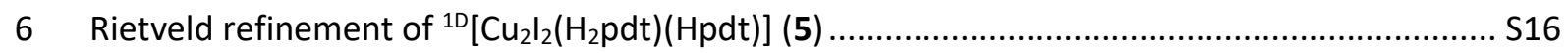

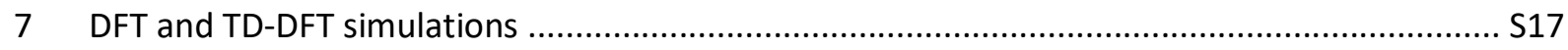

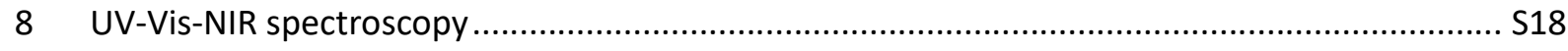

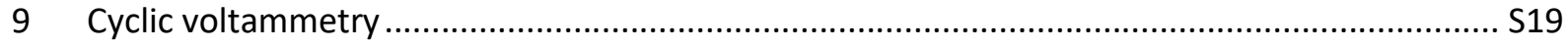

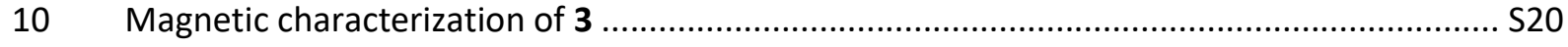

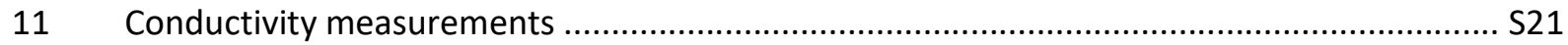

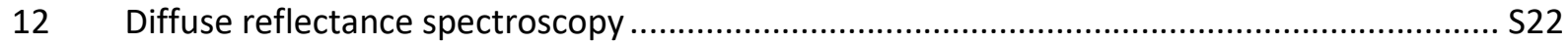

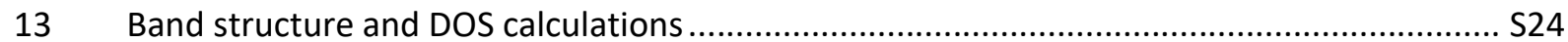

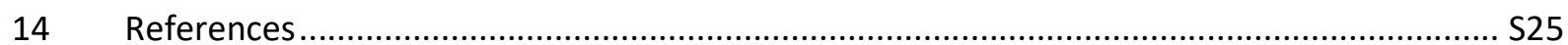




\section{Experimental section}

Reagent grade solvents were dried before use by standard techniques and stored under nitrogen over molecular sieve ( $3 \AA$ ). 2,3-Pyrazinedithiol ( $\mathrm{H}_{2} \mathrm{pdt}$ ) was synthesized according to the literature ${ }^{1-3}$. Melting points were determined with an Electrothermal 9100 instrument from Barnstead using open glass capillaries. Mass spectra were obtained using the positive ion electrospray ionization modus (ESI) on a microTOF instrument from Bruker Daltonik $\mathrm{GmbH}$. Infrared spectra $\left(4000-600 \mathrm{~cm}^{-1}\right)$ were recorded at $2 \mathrm{~cm}^{-1}$ resolution on a Bruker TENSOR 27 spectrometer. Elemental analyses were carried out on a VARIO EL elemental analyzer. ${ }^{1} \mathrm{H}$ NMR spectra were recorded on a Bruker Avance III HD $400 \mathrm{MHz}$ spectrometer in DMSO- $\mathrm{d}_{6}$ and were referenced to the residual solvent peak. The microwave synthesis reactor Monowave 400 from Anton Paar was used for microwave assisted synthesis, as indicated in the synthesis description.

$\mathrm{H}_{2}$ pdt: A solution of $\mathrm{NaSH} \cdot \times \mathrm{H}_{2} \mathrm{O}(9.68 \mathrm{~g}, 173 \mathrm{mmol}, 5.53 \mathrm{eq})^{*}$ in $30 \mathrm{~mL}$ degassed water was added to a solution of 2,3-dichloropyrazine $(4.66 \mathrm{~g}, 31.3 \mathrm{mmol}, 1 \mathrm{eq})$ in $40 \mathrm{~mL}$ methanol. The resulting yellow solution was refluxed for $6 \mathrm{~h}$ to produce a dark red suspension. The mixture was cooled to room temperature, and $35 \mathrm{~mL}$ of $2 \mathrm{M} \mathrm{HCl}$ was added dropwise to afford a heavy, dark-brown precipitate. The resulting suspension was stored at $-20^{\circ} \mathrm{C}$ for two days before the precipitate was filtered off, washed thoroughly with water and cold methanol, and dried under vacuum. The crude product ( $3.89 \mathrm{~g}$, $27.0 \mathrm{mmol}, 86.2 \%)$ was dissolved with $\mathrm{NaOH}(2.16 \mathrm{~g}, 54.0 \mathrm{mmol})$ in a degassed mixture of $50 \mathrm{~mL}$ methanol and $40 \mathrm{~mL}$ water, filtered, and again precipitated with $25 \mathrm{~mL}$ of $2 \mathrm{M} \mathrm{HCl}$. After filtration and washing with water and cold methanol, pure microcrystalline dark-red $\mathrm{H}_{2}$ pdt was obtained.

Yield: $3.75 \mathrm{~g}, 83 \%$. $\mathbf{T}_{\mathrm{m}}$ : $245^{\circ} \mathrm{C}$ (decomposition). EA: found: C: $33.29 \%, \mathrm{H}: 2.56 \%, \mathrm{~N}: 19.20 \%$; calculated for $\left(\mathrm{C}_{4} \mathrm{H}_{4} \mathrm{~N}_{2} \mathrm{~S}_{2}\right)$ : C: $33.31 \%, \mathrm{H}: 2.80 \%, \mathrm{~N}: 19.43 \%$. HR-MS (ESI): $\mathrm{m} / \mathrm{z}=166.971[\mathrm{M}+\mathrm{Na}]^{+}$, $182.947[\mathrm{M}+\mathrm{Na}]^{+} .{ }^{1} \mathrm{H}$ NMR (400 MHz, DMSO-d 6 ): $\delta[\mathrm{ppm}]=6.90\left(\mathrm{~s}, 2 \mathrm{H}_{\text {arom }}\right), 13.73(\mathrm{~s}, 2 \mathrm{H}, \mathrm{NH}) . \mathbf{I R}$ (ATR): $\tilde{v}\left[\mathrm{~cm}^{-1}\right]=3105(\mathrm{~m}), 3083(\mathrm{~m}), 3067(\mathrm{~m}), 3010(\mathrm{w}), 2892(\mathrm{~m}), 2769(\mathrm{w}), 1628(\mathrm{~m}), 1546(\mathrm{~m})$, $1526(\mathrm{~m}), 1478(\mathrm{~m}), 1412(\mathrm{w}), 1315(\mathrm{~m}), 1287(\mathrm{~m}), 1188(\mathrm{w}), 1149(\mathrm{~m}), 1133(\mathrm{~m}), 1070(\mathrm{~m}), 1050(\mathrm{~m})$, $850(w), 820(m), 804(m), 720(m)$.

[ $\mathrm{Cu}\left(\mathrm{H}_{2} \mathrm{pdt}\right)_{2}$ ] Cl (1): $\mathrm{CuCl}$ (495 mg, $\left.5 \mathrm{mmol}, 1 \mathrm{eq}\right)$ and $\mathrm{H}_{2} \mathrm{pdt}(1.44 \mathrm{~g}, 10 \mathrm{mmol}, 2 \mathrm{eq}$ ) were suspended in $160 \mathrm{~mL}$ of methanol. The resulting blue solution was filtered and reduced under vacuum at $15^{\circ} \mathrm{C}$ to obtain pure 1 as a dark blue microcrystalline powder.

Yield: $1.15 \mathrm{~g}, 59 \%$. EA: found: C: $25.02 \%, \mathrm{H}: 1.91 \%, \mathrm{~N}: 14.35 \%$; calculated for $\left(\mathrm{C}_{8} \mathrm{H}_{8} \mathrm{ClCuN}_{4} \mathrm{~S}_{4}\right)$ : C: $24.80 \%, \mathrm{H}: 2.09 \%, \mathrm{~N}: 14.46 \%$. HR-MS (ESI): $\mathrm{m} / \mathrm{z}=350.892$ [M-Cl] ${ }^{+}$. UV/Vis/NIR (CH $\left.{ }_{3} \mathrm{OH}\right): \lambda[\mathrm{nm}]$ $(\log \varepsilon)=265$ (4.24), 313 (3.66), 374 (3.95), 421 (3.81), 448 (3.67), 594 (3.97). ${ }^{1} \mathrm{H}$ NMR (400 MHz, DMSO-d $\left.\mathrm{d}_{6}\right): \delta[\mathrm{ppm}]=7.27\left(\mathrm{~s}, 4 \mathrm{H}, \mathrm{CH}_{\text {arom }}\right), 14.92(\mathrm{~s}(\mathrm{~b}), 4 \mathrm{H}, \mathrm{NH}) . \mathbf{I R}(\mathrm{KBr}): \tilde{v}\left[\mathrm{~cm}^{-1}\right]=3163(\mathrm{w}), 3110(\mathrm{~m})$, $3092(\mathrm{~m}), 3064(\mathrm{~m}), 2950(\mathrm{~m}), 2901(\mathrm{~m}), 2855(\mathrm{~m}), 2765(\mathrm{~m}), 2710(\mathrm{~m}), 2665(\mathrm{~m}), 2610(\mathrm{~m}), 2347(\mathrm{w})$, $1623(\mathrm{~s}), 1522(\mathrm{w}), 1484(\mathrm{~m}), 1475(\mathrm{~m}), 1405(\mathrm{w}), 1328(\mathrm{~s}), 1300(\mathrm{~s}), 1200(\mathrm{w}), 1180(\mathrm{~m}), 1166(\mathrm{~m})$, $1149(\mathrm{~s}), 1084(\mathrm{~m}), 1050(\mathrm{~s}), 929(\mathrm{w}), 912(\mathrm{~m}), 987(\mathrm{w}), 817(\mathrm{~m}), 751(\mathrm{~m}), 733(\mathrm{~m}), 706(\mathrm{w}), 633(\mathrm{w})$, $620(w)$.

\footnotetext{
${ }^{*}$ Anhydrous basis
} 
${ }^{10}[\mathrm{Ag}(\mathrm{Hpdt})]\left(2^{\mathrm{Ag}}\right): \mathrm{H}_{2} \mathrm{pdt}(144 \mathrm{mg}, 1 \mathrm{mmol}, 1 \mathrm{eq})$ and $\mathrm{Ag}_{2} \mathrm{SO}_{4}(156 \mathrm{mg}, 0.5 \mathrm{mmol}, 0.5 \mathrm{eq})$ were suspended in $120 \mathrm{~mL}$ methanol and refluxed for $21 \mathrm{~h}$. The resulting orange precipitate was filtered off, washed thoroughly with methanol, and air-dried.

Yield: $213 \mathrm{mg}, 85 \%$. EA: found: C: $17.44 \%, \mathrm{H}: 1.42 \%, \mathrm{~N}: 10.27 \%$; calculated for $\left(\mathrm{C}_{4} \mathrm{H}_{3} \mathrm{AgN}_{2} \mathrm{~S}_{2} \cdot \mathrm{H}_{2} \mathrm{O}\right)$ : C: $17.85 \%, \mathrm{H}: 1.87 \%, \mathrm{~N}: 10.41 \%$.). One water molecule per formula unit is assumed due to the porosity of the compound with a solvent accessible volume of $16 \mathrm{Vol} \%(\mathrm{Z}=4)$. IR $(\mathrm{KBr})$ : $\tilde{v}\left[\mathrm{~cm}^{-1}\right]=3581(\mathrm{w}), 3087(\mathrm{w}), 2040(\mathrm{w}), 1604(\mathrm{~m}), 1534(\mathrm{w}), 1378(\mathrm{~s}), 1207(\mathrm{w}), 1130(\mathrm{~s}), 1045(\mathrm{~s})$, $814(m), 643(m), 502(w), 445(w), 430(w)$.

Single crystals were obtained under solvothermal conditions. A Teflon lined steel autoclave was loaded with $\mathrm{H}_{2}$ pdt ( $14.4 \mathrm{mg}, 0.1 \mathrm{mmol}, 1 \mathrm{eq}$ ), $\mathrm{Ag}_{2} \mathrm{SO}_{4}(15.6 \mathrm{mg}, 0.05 \mathrm{mmol}, 0.5 \mathrm{eq}$ ), and $5 \mathrm{~mL}$ methanol, sealed, and the reaction mixture was heated within $10 \mathrm{~h}$ up to $100^{\circ} \mathrm{C}$. The temperature was kept on a constant level for $24 \mathrm{~h}$ before cooling the autoclave to room temperature during a period of $10 \mathrm{~h}$. Besides decomposition products like sulfur and amorphous precipitate, 250 to $300 \mu \mathrm{m}$ long, thin, red needles were obtained.

${ }^{1 D}[\mathrm{Cu}(\mathrm{Hpdt})]$ (2 $\left.{ }^{\mathrm{Cu}}\right):\left[\mathrm{Cu}\left(\mathrm{H}_{2} \mathrm{pdt}\right)_{2}\right] \mathrm{Cl}(\mathbf{1})(77.5 \mathrm{mg}, 0.2 \mathrm{mmol}, 1 \mathrm{eq})$ and $\mathrm{Cul}(38.1 \mathrm{mg}, 0.2 \mathrm{mmol}, 1 \mathrm{eq})$ were suspended in $2 \mathrm{~mL}$ acetonitrile and $10 \mathrm{~mL}$ methanol in a $30 \mathrm{ml}$ microwave vessel. Latter was sealed and heated to $100^{\circ} \mathrm{C}$ in the microwave oven. After $1 \mathrm{~h}$ of heating, the vessel was cooled down to room temperature. The resulting dark red needles were filtered off and washed thoroughly with methanol and acetonitrile.

Yield: $70 \mathrm{mg}, 85 \%$. EA: found: C: $23.02 \%, \mathrm{H}: 1.27 \%, \mathrm{~N}: 13.50 \%$; calculated for $\left(\mathrm{C}_{4} \mathrm{H}_{3} \mathrm{CuN}_{2} \mathrm{~S}_{2}\right)$ : C: $23.24 \%, H: 1.46 \%, \quad N: 13.55 \%$. IR (KBr): $\tilde{v}\left[\mathrm{~cm}^{-1}\right]=3077(\mathrm{w}), 2040(\mathrm{w}), 1597(\mathrm{~m}), 1401(\mathrm{~m})$, $1265(\mathrm{w}), 1231(\mathrm{~m}), 1136(\mathrm{~s}), 1081(\mathrm{w}), 1044(\mathrm{~s}), 802(\mathrm{~m}), 656(\mathrm{~m}), 501(\mathrm{w}), 447(\mathrm{w})$.

Single crystals were obtained using a slightly modified routine. A Teflon lined steel autoclave was loaded with $\mathrm{H}_{2}$ pdt ( $14.2 \mathrm{mg}, 0.1 \mathrm{mmol}, 1 \mathrm{eq}$ ), CuSCN (12.2 mg, $0.1 \mathrm{mmol}, 1 \mathrm{eq}$ ), and $5 \mathrm{~mL}$ methanol, sealed, and the reaction mixture was heated to $120^{\circ} \mathrm{C}$ within $1 \mathrm{~h}$. The temperature was kept on a constant level for $1 \mathrm{~h}$ before cooling the autoclave to room temperature during a period of $70 \mathrm{~h}$. Beside $300 \mu \mathrm{m}$ long, dark red needles of $\mathbf{2}^{\mathrm{Cu}}$, a small amount of unreacted CuSCN and bright red thin needles, characterized as $\left[\mathrm{Cu}(\mathrm{Hpdt})_{2}\right](\mathbf{3})$, were obtained.

[Cu(Hpdt) $)_{2}$ (3): $\left[\mathrm{Cu}\left(\mathrm{H}_{2} \mathrm{pdt}\right)_{2}\right] \mathrm{Cl}(\mathbf{1})(29.1 \mathrm{mg}, 0.075 \mathrm{mmol})$ was dissolved in $9 \mathrm{~mL}$ methanol in a $30 \mathrm{ml}$ microwave vessel, which was sealed and heated to $140{ }^{\circ} \mathrm{C}$ in the microwave oven. After $40 \mathrm{~min}$ of heating, the vessel was cooled down with compressed air. The resulting red microcrystalline precipitate was filtered off and washed thoroughly with methanol and acetonitrile.

Yield: $18 \mathrm{mg}, 69 \%$. EA: found: C: $27.62 \%, \mathrm{H}: 1.67 \%, \mathrm{~N}: 15.97 \%$; calculated for $\left(\mathrm{C}_{8} \mathrm{H}_{6} \mathrm{CuN}_{4} \mathrm{~S}_{4}\right)$ : C: $27.45 \%, H: 1.73 \%, \mathrm{~N}: 16.01 \%$. UV/Vis/NIR (DMSO): $\lambda$ [nm] (log $\varepsilon)=287$ (4.05), 443 (4.34). IR (KBr): $\tilde{v}\left[\mathrm{~cm}^{-1}\right]=3080(\mathrm{~m}), 2507(\mathrm{~m}, \mathrm{~b}), 1992(\mathrm{~m}, \mathrm{~b}), 1853(\mathrm{w}), 1719(\mathrm{w}), 1608(\mathrm{~m}), 1540(\mathrm{~m}), 1408(\mathrm{~m})$, $1389(\mathrm{~s}), 1243(\mathrm{~m}), 1141(\mathrm{~s}), 1071(\mathrm{~m}), 1041(\mathrm{~s}), 815(\mathrm{~m}), 796(\mathrm{~m}), 653(\mathrm{~s}), 502(\mathrm{~m}), 469(\mathrm{w}), 455(\mathrm{w})$, $431(w)$. 
${ }^{10}\left[\mathrm{Cu}\left(\mathrm{H}_{2} \mathrm{pdt}\right)\right.$ I] (4): Microwave synthesis: $\mathrm{H}_{2} \mathrm{pdt}(28.4 \mathrm{mg}, 0.2 \mathrm{mmol}, 1 \mathrm{eq})$ and Cul ( $38.1 \mathrm{mg}, 0.2 \mathrm{mmol}$, 1 eq) in $20 \mathrm{~mL}$ acetonitrile were heated to $80^{\circ} \mathrm{C}$ in a $30 \mathrm{~mL}$ vessel in the microwave oven. The temperature was kept for $2 \mathrm{~h}$ without stirring, before the vessel was cooled to $55^{\circ} \mathrm{C}$. The resulting dark black needles ( $40 \mathrm{mg}, 59 \%$ ), suitable for single crystal diffraction, were filtered off and washed with acetonitrile. Phase purity was confirmed by PXRD. Reflux synthesis: $\mathrm{H}_{2}$ pdt ( $115 \mathrm{mg}, 0.8 \mathrm{mmol}, 1 \mathrm{eq}$ ) and Cul (152 mg, $0.8 \mathrm{mmol}, 1 \mathrm{eq}$ ) were suspended in $80 \mathrm{~mL}$ of acetonitrile and refluxed for $2 \mathrm{~h}$. The resulting black microcrystalline precipitate was filtered off, washed with acetonitrile, and dried on air.

Yield: $191 \mathrm{mg}, 71 \%$. EA: found: C: $14.89 \%, \mathrm{H}: 1.15 \%, \mathrm{~N}: 8.71 \%$; calculated for $\left(\mathrm{C}_{4} \mathrm{H}_{4} \mathrm{CuIN}_{2} \mathrm{~S}_{2}\right)$ : C: $14.35 \%, H: 1.21 \%, \mathrm{~N}: 8.37 \%$. IR (KBr): $\tilde{v}\left[\mathrm{~cm}^{-1}\right]=3235(\mathrm{~s}), 3163(\mathrm{~m}), 3133(\mathrm{~m}), 3074(\mathrm{~m}), 3036(\mathrm{w})$, $2979(\mathrm{~m}), 1819(\mathrm{w}), 1623(\mathrm{~s}), 1527(\mathrm{~s}), 1485(\mathrm{~s}), 1401(\mathrm{~m}), 1389(\mathrm{~m}), 1325(\mathrm{~s}), 1304(\mathrm{~s}), 1140(\mathrm{~s})$, $1087(\mathrm{~m}), 1074(\mathrm{w}), 1039(\mathrm{~s}), 816(\mathrm{~s}), 798(\mathrm{~m}), 744(\mathrm{~m}), 710(\mathrm{~s}), 688(\mathrm{~m}), 654(\mathrm{~m}), 507(\mathrm{~m}), 441(\mathrm{~m})$. 


\section{NMR spectroscopy}

The ${ }^{1} \mathrm{H}$ NMR spectrum of $\left[\mathrm{Cu}\left(\mathrm{H}_{2} \mathrm{pdt}\right)_{2}\right] \mathrm{Cl}(\mathbf{1})$ was recorded on a Bruker Avance III HD $-400 \mathrm{MHz}$ spectrometer in DMSO- $d_{6}$ and was referenced to the residual solvent peak.

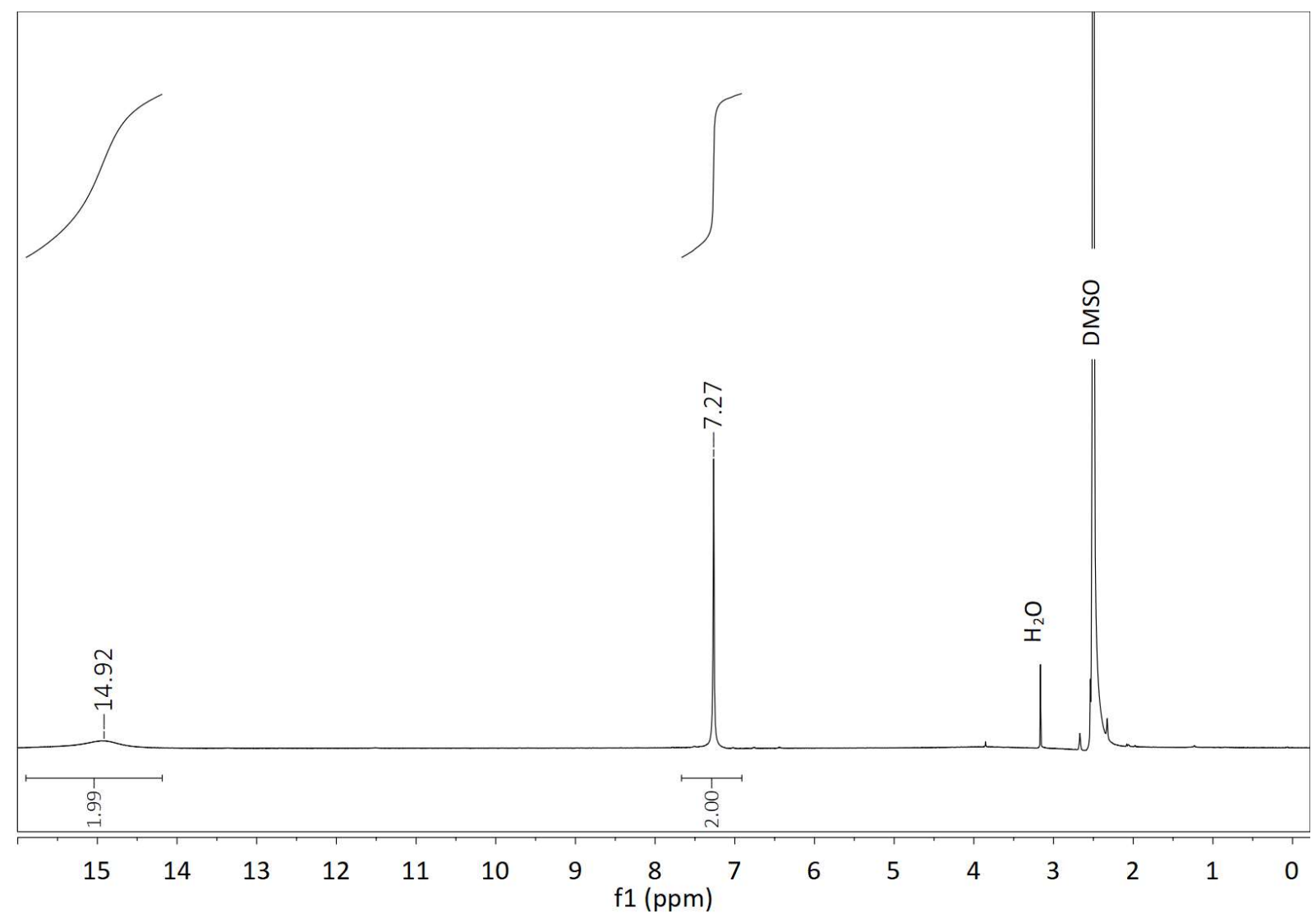

Figure SI-1: ${ }^{1} \mathrm{H}$ NMR spectrum of $\left[\mathrm{Cu}\left(\mathrm{H}_{2} \mathrm{pdt}\right)_{2}\right] \mathrm{Cl}(\mathbf{1})$ in DMSO-d 6 (2.50 ppm). 


\section{PXRD measurements}

PXRD measurements were carried out on a STOE STADI-P diffractometer equipped with a sealed $\mathrm{Cu}$ $X$-ray tube and a germanium (111) monochromator crystal $\left(\lambda\left(\mathrm{Cu} \mathrm{K} \alpha_{1}\right)=154.060 \mathrm{pm}\right)$.
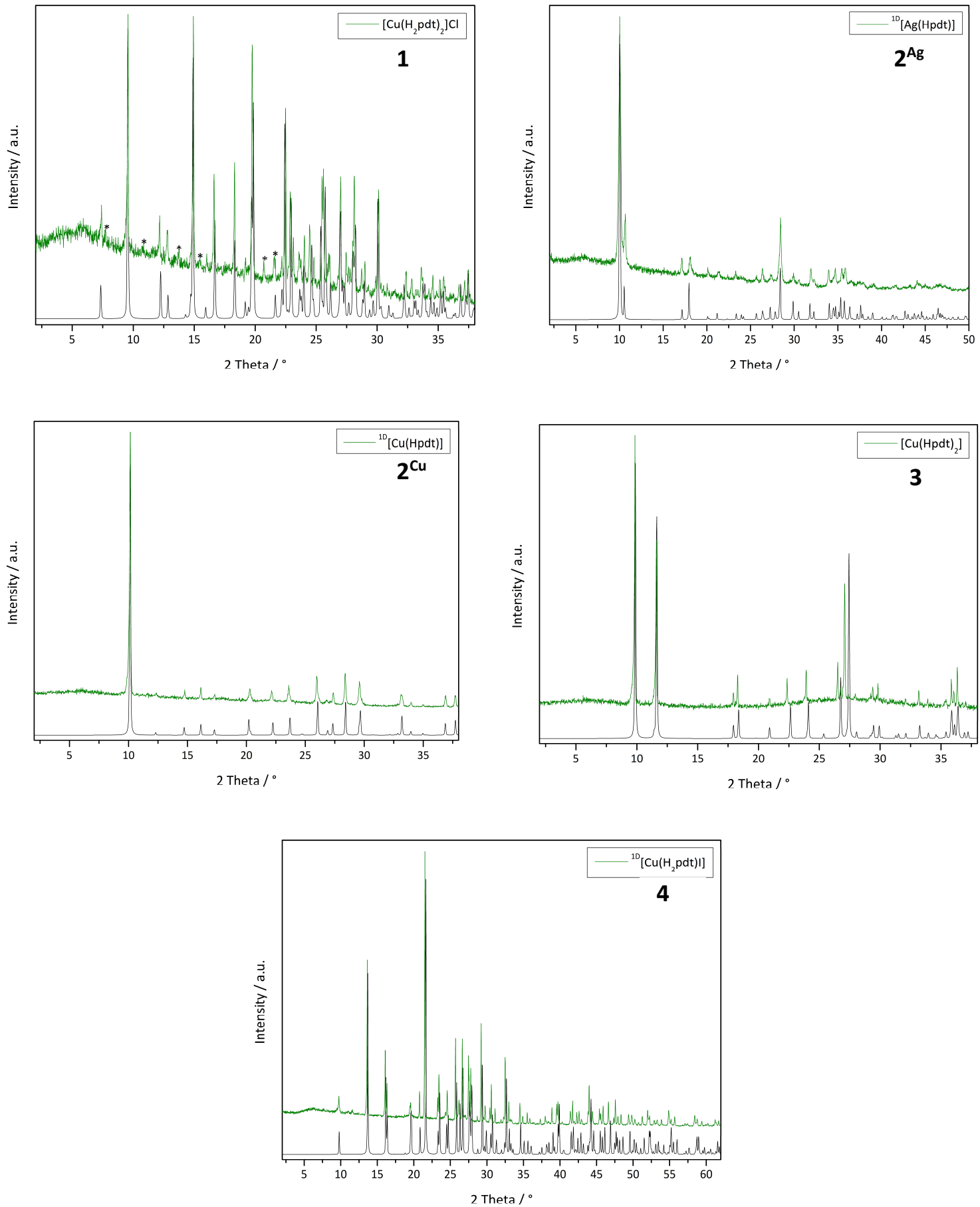

Figure SI-2: PXRD of 1, $\mathbf{2}^{\mathrm{Ag}}, \mathbf{2}^{\mathrm{Cu}}, \mathbf{3}$, and $\mathbf{4}$ in green and the corresponding simulated diffraction patterns (black) based on single crystal data. The PXRD patterns of $\mathbf{2}^{\mathrm{Ag}}$ and $\mathbf{4}$ are recorded after synthesis under reflux. The reflections marked with an asterisk * in the PXRD pattern of 1 belong to the triclinic phase of the complex, $\mathbf{1}^{\prime}$, which is described in SI section 5.4. 


\section{Temperature dependent PXRD measurements}

The temperature dependent PXRD measurements were carried out on a STOE STADI-P diffractometer with a high-temperature attachment (Type 2416 by EUROTHERM) using $\mathrm{Cu} \mathrm{K \alpha _{1 }}$ radiation $(\lambda=154.060 \mathrm{pm})$. The samples were measured in glass capillaries.

$\left[\mathrm{Cu}\left(\mathrm{H}_{2} \mathrm{pdt}\right)_{2}\right] \mathrm{Cl}(1)$

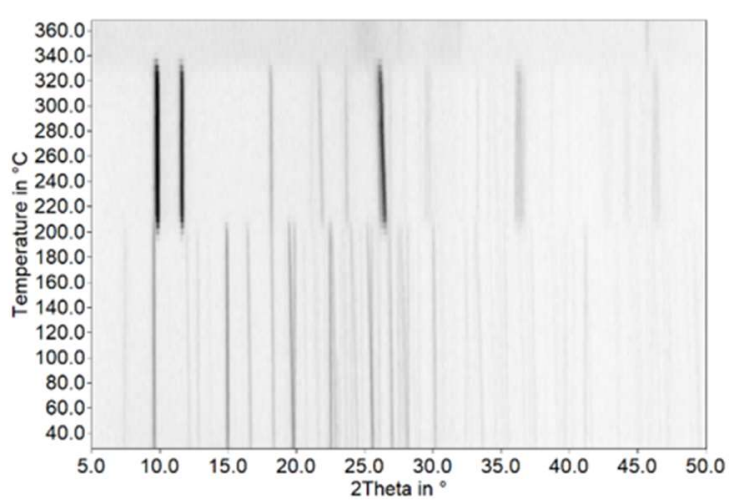

${ }^{1 D}[\mathrm{Cu}(\mathrm{Hpdt})]\left(2^{\mathrm{Cu}}\right)$

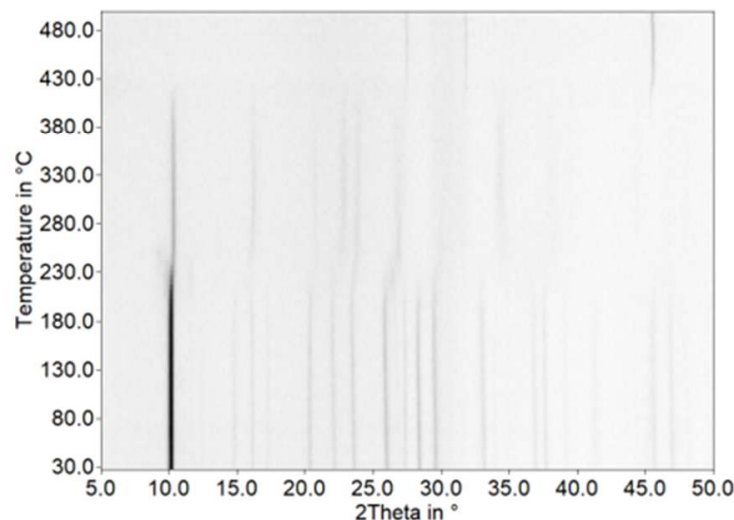

${ }^{1 \mathrm{D}}[\mathrm{Ag}(\mathrm{Hpdt})]\left(2^{\mathrm{Ag}}\right)$

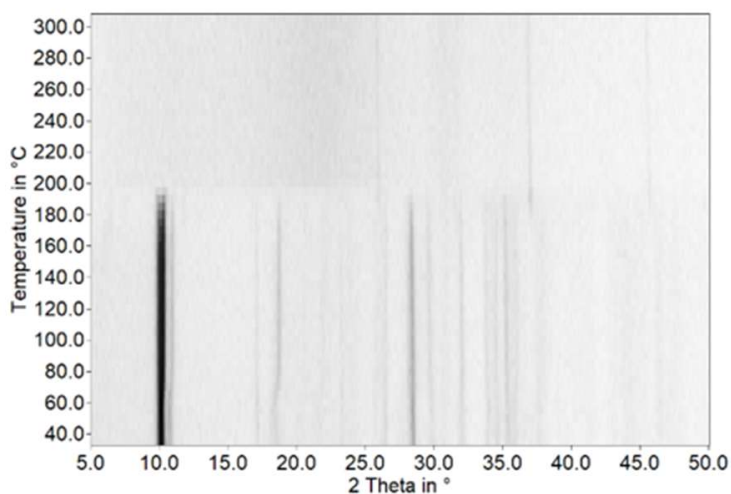

${ }^{10}\left[\mathrm{Cu}\left(\mathrm{H}_{2} \mathrm{pdt}\right) \mathrm{I}(4)\right.$

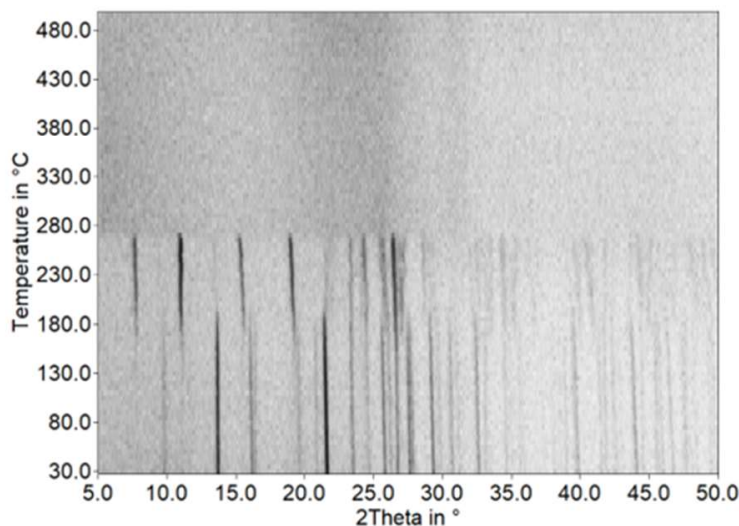

Figure SI-3: Two-dimensional representation (Guinier-Simon diagrams) of the TD-PXRD measurements of $\mathbf{1}, \mathbf{2}^{\mathrm{Ag}}, \mathbf{2}^{\mathrm{Cu}}$, and $\mathbf{4}$.

The fully protonated $\mathrm{Cu}(\mathrm{I})$ complex 1 transformed into the $\mathrm{Cu}(\mathrm{II})$ complex 3 at $200{ }^{\circ} \mathrm{C}$, as shown in Figure SI-4, by comparing the PXRD pattern of 1 at $260^{\circ} \mathrm{C}$ with the simulated diffraction pattern of 3 .

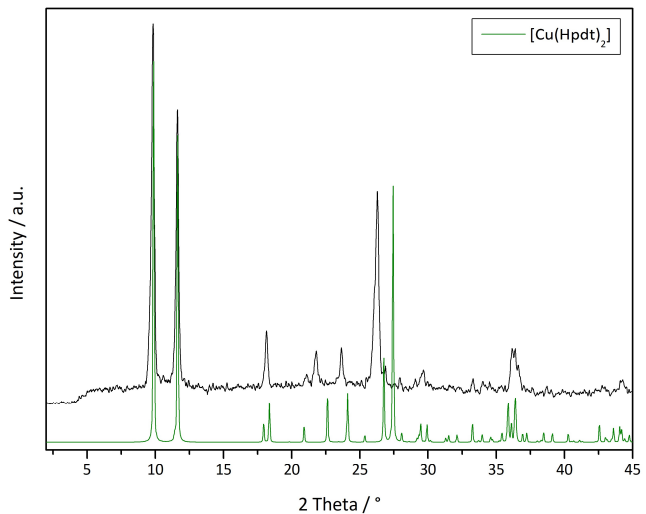

Figure SI-4: PXRD of 1 at $260^{\circ} \mathrm{C}$ in black and simulated diffraction pattern of $\mathbf{3}$ (based on single crystal data measured at $-93^{\circ} \mathrm{C}$ ) in green. 


\section{Single crystal structure data}

\subsection{General information}

The single crystal X-ray diffraction data were collected at 180 or $100 \mathrm{~K}$ on a StadiVari diffractometer (Stoe \& Cie $\mathrm{GmbH}$ ) equipped with a Dectris Pilatus 300K detector using $\mathrm{Cu} \mathrm{K \alpha}$ radiation $(\lambda=154.186 \mathrm{pm})$ of an $\mathrm{X}$-ray microsource. Unit cell determination, integration of the intensities, and corrections for Lorentz, polarization, and absorption effects, as well as a scaling correction, were performed with the X-AREA software. ${ }^{4}$ The structures were solved and refined using SHELXS/SHELXT and SHELXL, ${ }^{5,6}$ implemented in WinGX. ${ }^{7}$ All non-hydrogen atoms were refined anisotropically. Hydrogen atoms on the pyrazine carbon atoms were included on idealized positions with a $\mathrm{C}-\mathrm{H}$ distance of $95 \mathrm{pm}$. In the crystal structures of $\mathrm{H}_{2} \mathrm{pdt}, \mathbf{1}, \mathbf{1}^{\prime}$, and $\mathbf{2}^{\mathrm{Cu}}$, the hydrogen atoms on the pyrazine nitrogen atoms were refined freely with an isotropic displacement factor. In the structures of $\mathbf{2}^{\mathrm{Ag}}, \mathbf{3}$, and $\mathbf{4}$, the data sets did not permit a free refinement of the acidic pyrazine protons. The determined oxidation states of the metal ions, however, strongly point towards a protonation of the pyrazine units and the protons were included on idealized positions with $\mathrm{N}-\mathrm{H}$ distances of $88 \mathrm{pm}$. Graphical representations were generated with Diamond. ${ }^{8}$ 
Table SI-1: Single crystal structure data of $\mathrm{H}_{2} \mathrm{pdt}, \mathbf{1}, \mathbf{1}^{\mathbf{\prime}}$ and $\mathbf{2}^{\mathrm{Ag}}$.

\begin{tabular}{|c|c|c|c|c|}
\hline Compound & $\mathrm{H}_{2} \mathrm{pdt}$ & {$\left[\mathrm{Cu}\left(\mathrm{H}_{2} \mathrm{pdt}\right)_{2}\right] \mathrm{Cl}(\mathbf{1})$} & {$\left[\mathrm{Cu}\left(\mathrm{H}_{2} \mathrm{pdt}\right)_{2}\right] \mathrm{Cl}\left(\mathbf{1}^{\prime}\right)$} & ${ }^{1 D}[\mathrm{Ag}(\mathrm{Hpdt})]\left(\mathbf{2}^{\mathrm{Ag}}\right)$ \\
\hline CCDC deposition number & 2017470 & 2017472 & 2017471 & 2017474 \\
\hline Crystal size / mm & $0.01 \times 0.01 \times 0.13$ & $0.19 \times 0.04 \times 0.04$ & $0.03 \times 0.12 \times 0.13$ & $0.05 \times 0.01 \times 0.01$ \\
\hline Formula & $\mathrm{C}_{4} \mathrm{H}_{4} \mathrm{~N}_{2} \mathrm{~S}_{2}$ & $\mathrm{C}_{8} \mathrm{H}_{8} \mathrm{ClCu} \mathrm{N} \mathrm{S}_{4}$ & $\mathrm{C}_{8} \mathrm{H}_{8} \mathrm{Cl} \mathrm{Cu} \mathrm{N} \mathrm{S}_{4}$ & $\mathrm{C}_{4} \mathrm{H}_{3} \mathrm{Ag} \mathrm{N}_{2} \mathrm{~S}_{2}$ \\
\hline $\mathrm{M} / \mathrm{g} \cdot \mathrm{mol}^{-1}$ & 144.21 & 387.41 & 387.41 & 251.07 \\
\hline Temperature / K & 180 & 180 & 100 & 180 \\
\hline Crystal system & monoclinic & monoclinic & triclinic & monoclinic \\
\hline Space group & $P 2_{1} / c$ & $P 2_{1} / c$ & $P \overline{1}$ & $P 2_{1} / n$ \\
\hline Unit cell parameters / pm, ${ }^{\circ}$ & $\begin{array}{l}a=396.81(2) \\
b=1076.56(3) \\
c=1325.47(6) \\
\alpha=90 \\
\beta=94.020(4) \\
\nu=90\end{array}$ & $\begin{array}{l}a=1203.76(5) \\
b=1444.46(4) \\
c=783.22(3) \\
\alpha=90 \\
\beta=90.863(3) \\
\nu=90\end{array}$ & $\begin{array}{l}a=741.76(4) \\
b=824.55(4) \\
c=1151.84(5) \\
\alpha=83.953(4) \\
\beta=82.861(4) \\
\gamma=84.411(4)\end{array}$ & $\begin{array}{l}a=1032.38(3) \\
b=409.08(2) \\
c=1677.02(9) \\
\alpha=90 \\
\beta=90.567(4) \\
\gamma=90\end{array}$ \\
\hline Volume $/ 10^{6} \mathrm{pm}^{3}$ & $564.83(4)$ & 1361.70(9) & $692.59(6)$ & $708.21(6)$ \\
\hline Z & 4 & 4 & 2 & 4 \\
\hline Density / $\mathrm{g} \cdot \mathrm{cm}^{3}$ & 1.70 & 1.89 & 1.86 & 2.36 \\
\hline Absorption coefficient $\mu / \mathrm{mm}^{-1}$ & 7.54 & 9.70 & 9.53 & 27.59 \\
\hline$\theta$ range $/^{\circ}$ & $5.3-70.0$ & $3.6-70.0$ & $3.9-70.7$ & $5.0-70.0$ \\
\hline No. of measured reflections & 13755 & 13989 & 11104 & 7528 \\
\hline No. of independent reflections & 1060 & 2529 & 2567 & 1332 \\
\hline No. of observed reflections & 914 & 2185 & 2483 & 1149 \\
\hline $\mathrm{R}_{\text {int }}$ & 0.057 & 0.019 & 0.011 & 0.035 \\
\hline Parameters & 81 & 179 & 179 & 82 \\
\hline$R_{1}(I>2 \sigma(I))$ & 0.033 & 0.030 & 0.018 & $0.035^{*}$ \\
\hline$w R_{2}$ (all data) & 0.092 & 0.088 & 0.047 & $0.089^{*}$ \\
\hline Goof & 1.069 & 1.045 & 1.113 & 1.035 \\
\hline $\begin{array}{l}\text { Max. / min. residual e- density / } \\
10^{-6} \mathrm{pm}^{-3}\end{array}$ & $0.36 /-0.39$ & $0.83 /-0.37$ & $0.30 /-0.23$ & $1.42 /-0.81$ \\
\hline
\end{tabular}

The PLATON/SQUEEZE-routine ${ }^{9}$ was applied to account for diffuse electron density in the pores. (Total potential solvent volume: $16 \%$; before SQUEEZE: $\mathrm{R}_{1}=0.044$ ). 
Table SI-2: Single crystal structure data of $\mathbf{2}^{\mathrm{Cu}}, \mathbf{3}$, and $\mathbf{4}$.

\begin{tabular}{|c|c|c|c|}
\hline Compound & ${ }^{1 D}[\mathrm{Cu}(\mathrm{Hpdt})]\left(2^{\mathrm{Cu}}\right)$ & {$\left[\mathrm{Cu}(\mathrm{Hpdt})_{2}\right](3)$} & ${ }^{1 D}\left[\mathrm{Cu}\left(\mathrm{H}_{2} \mathrm{pdt}\right) \mathrm{I}\right](\mathbf{4})$ \\
\hline CCDC deposition number & 2017473 & 2017475 & 2017476 \\
\hline Crystal size / mm & $0.08 \times 0.09 \times 0.09$ & $0.09 \times 0.01 \times 0.01$ & $0.08 \times 0.01 \times 0.01$ \\
\hline Formula & $\mathrm{C}_{4} \mathrm{H}_{3} \mathrm{Cu} \mathrm{N} \mathrm{N}_{2}$ & $\mathrm{C}_{8} \mathrm{H}_{6} \mathrm{Cu} \mathrm{N} \mathrm{S}_{4}$ & $\mathrm{C}_{4} \mathrm{H}_{4} \mathrm{Cu} I \mathrm{~N}_{2} \mathrm{~S}_{2}$ \\
\hline $\mathrm{M} / \mathrm{g} \cdot \mathrm{mol}^{-1}$ & 206.74 & 349.95 & 334.65 \\
\hline Temperature / K & 180 & 180 & 180 \\
\hline Crystal system & orthorhombic & triclinic & monoclinic \\
\hline Space group & $\mathrm{Pna}_{1}$ & $P \overline{1}$ & $P 2_{1} / c$ \\
\hline Unit cell parameters / pm, ${ }^{\circ}$ & $\begin{array}{l}a=1098.96(7) \\
b=1434.71(7) \\
c=415.34(2) \\
\alpha=90 \\
\beta=90 \\
\gamma=90\end{array}$ & $\begin{array}{l}a=399.84(4) \\
b=862.76(8) \\
c=990.63(8) \\
\alpha=64.908(6) \\
\beta=82.206(7) \\
\gamma=79.854(7)\end{array}$ & $\begin{array}{l}a=647.36(4) \\
b=688.54(3) \\
c=1809.5(1) \\
\alpha=90 \\
\beta=93.491(5) \\
\gamma=90\end{array}$ \\
\hline Volume $/ 10^{6} \mathrm{pm}^{3}$ & $654.86(6)$ & $303.93(5)$ & $805.05(8)$ \\
\hline Z & 4 & 1 & 4 \\
\hline Density / $\mathrm{g} \cdot \mathrm{cm}^{3}$ & 2.10 & 1.91 & 2.76 \\
\hline Absorption coefficient $\mu / \mathrm{mm}^{-1}$ & 9.84 & 8.81 & 38.17 \\
\hline$\theta$ range $/^{\circ}$ & $5.1-67.4$ & $4.9-69.9$ & $4.9-70.0$ \\
\hline Number of measured reflections & 6635 & 4787 & 11969 \\
\hline Number of independent reflections & 1166 & 1123 & 1523 \\
\hline Number of observed reflections & 866 & 950 & 1388 \\
\hline $\mathrm{R}_{\text {int }}$ & 0.124 & 0.023 & 0.046 \\
\hline Parameters & 86 & 79 & 91 \\
\hline$R_{1}(I>2 \sigma(I))$ & $0.047^{\#}$ & 0.026 & 0.047 \\
\hline$w \mathrm{R}_{2}$ (all data) & $0.118^{\#}$ & 0.064 & 0.131 \\
\hline Goof & 0.988 & 1.046 & 1.044 \\
\hline Max. / min. residual e- density / $10^{-6} \mathrm{pm}^{-3}$ & $0.56 /-0.41$ & $0.36 /-0.31$ & $2.34^{*} /-1.12^{*}$ \\
\hline
\end{tabular}

\#: The Flack x parameter was determined from 307 selected quotients to be -0.01(9) (Pearson's method).

*: The highest peak and deepest hole of residing electron density are located $69 \mathrm{pm}$ and $108 \mathrm{pm}$ next to the iodine atom. 
5.2 Selected bond lengths in $\left[\mathrm{Cu}\left(\mathrm{H}_{2} \mathrm{pdt}\right)_{2}\right] \mathrm{Cl}(1),\left[\mathrm{Cu}(\mathrm{Hpdt})_{2}\right](3)$, and ${ }^{1 \mathrm{D}}\left[\mathrm{Cu}\left(\mathrm{H}_{2} \mathrm{pdt}\right) \mathrm{I}\right](4)$

Table Sl-3: Selected distances (in pm) and angles (in ${ }^{\circ}$ ) in 1 . Symmetry codes: a (1-x, 1-y, 1-z), b (2-x, $\left.-0.5+y, 0.5-z\right)$, $c(x, y, 1+z)$.

\begin{tabular}{lllr}
$\mathrm{Cu}^{+}$coordination & & $\mathrm{H}_{2}$ pdt ligand and hydrogen bonds \\
\hline Cu1-S1 & $231.28(9)$ & $\mathrm{C} 1-\mathrm{S} 1$ & $167.2(3)$ \\
Cu1-S2 & $227.70(8)$ & $\mathrm{C} 2-\mathrm{S} 2$ & $168.0(3)$ \\
$\mathrm{Cu} 1-\mathrm{S} 3$ & $\mathrm{C} 5-\mathrm{S} 3$ & $169.5(3)$ \\
$\mathrm{Cu} 1-\mathrm{S} 4$ & $231.72(9)$ & $\mathrm{C} 6-\mathrm{S} 4$ & $167.7(3)$ \\
& $228.88(9)$ & $\mathrm{C} 1-\mathrm{C} 2$ & $146.9(4)$ \\
$\mathrm{S} 1-\mathrm{Cu} 1-\mathrm{S} 2$ & $\mathrm{C} 5-\mathrm{C} 6$ & $146.5(4)$ \\
S3-Cu1-S4 & $91.80(3)$ & $\mathrm{N} 3 \cdots \mathrm{Cl} 1(\mathrm{~N} 3-\mathrm{H} 3 \cdots \mathrm{Cl} 1)$ & $306.4(3)$ \\
$\mathrm{S} 1-\mathrm{Cu} 1-\mathrm{S} 3$ & $92.04(3)$ & $\mathrm{N} 2 \cdots \mathrm{Cl} 1 \mathrm{a}(\mathrm{N} 2-\mathrm{H} 2 \cdots \mathrm{Cl} 1 \mathrm{a})$ & $311.8(2)$ \\
$\mathrm{S} 2-\mathrm{Cu} 1-\mathrm{S} 4$ & $117.33(3)$ & $\mathrm{N} 4 \cdots \mathrm{Cl} 1 \mathrm{~b}(\mathrm{~N} 4-\mathrm{H} 4 \cdots \mathrm{Cl} 1 \mathrm{~b})$ & $308.7(3)$ \\
& $127.04(4)$ & $\mathrm{N} 1 \cdots \mathrm{S} 3 \mathrm{C}(\mathrm{N} 1-\mathrm{H} 1 \cdots \mathrm{S} 3 \mathrm{c})$ & $332.9(3)$
\end{tabular}

Table SI-4: Selected distances (in pm) and angles (in ${ }^{\circ}$ ) in $\mathbf{3}$. Symmetry code: a $(-x+1,-y,-z+1)$.

\begin{tabular}{llll}
$\mathrm{Cu}^{2+}$ coordination & & $\mathrm{Hpdt}$ ligand & \\
\hline $\mathrm{Cu1}-\mathrm{S} 1$ & $228.00(6)$ & $\mathrm{C} 1-\mathrm{S} 1$ & $171.1(3)$ \\
$\mathrm{Cu1}-\mathrm{S} 2$ & $227.80(6)$ & $\mathrm{C} 2-\mathrm{S} 2$ & $171.0(2)$ \\
& & $\mathrm{C} 1-\mathrm{C} 2$ & $145.2(3)$ \\
$\mathrm{S} 1-\mathrm{Cu} 1-\mathrm{S} 2$ & $90.54(2)$ & $\mathrm{C} 1-\mathrm{N} 1$ & $133.4(3)$ \\
S1-Cu1-S1a & 180 & $\mathrm{C} 2-\mathrm{N} 2$ & $133.4(3)$ \\
S1-Cu1-S2a & $89.46(2)$ & $\mathrm{C} 4-\mathrm{N} 1$ & $135.8(3)$ \\
& & $\mathrm{C} 3-\mathrm{N} 2$ & $135.9(3)$ \\
& & $\mathrm{C} 3-\mathrm{C} 4$ & $135.4(4)$
\end{tabular}

Table SI-5: Selected distances (in pm) and angles (in ${ }^{\circ}$ ) in 4. Symmetry codes: a (2-x, -0.5+y, 0.5-z), b (2-x, 0.5+y, 0.5-z).

\begin{tabular}{llll}
$\mathrm{Cu}^{+}$coordination & \multicolumn{3}{c}{$\mathrm{H}_{2}$ pdt ligand } \\
\hline Cu1-S1 & $233.6(2)$ & $\mathrm{C} 1-\mathrm{S} 1$ & $169.9(6)$ \\
Cu1-S2 & $230.1(2)$ & $\mathrm{C} 2-\mathrm{S} 2$ & $167.8(6)$ \\
Cu1-S1b & $239.3(2)$ & $\mathrm{C} 1-\mathrm{C} 2$ & $145.5(8)$ \\
Cu1-I1 & $251.77(9)$ & $\mathrm{C} 1-\mathrm{N} 1$ & $133.8(9)$ \\
S1-Cu1-S2 & $90.12(6)$ & $\mathrm{C} 2-\mathrm{N} 2$ & $135.4(7)$ \\
S1-Cu1-I1 & $117.14(5)$ & $\mathrm{C} 4-\mathrm{N} 1$ & $137.3(9)$ \\
S2-Cu1-I1 & $128.34(5)$ & $\mathrm{C} 3-\mathrm{N} 2$ & $136.0(8)$ \\
S1-Cu1-S1b & $107.62(4)$ & $\mathrm{C} 3-\mathrm{C} 4$ & $135(1)$ \\
S2-Cu1-S1b & $97.74(6)$ & & \\
Cu1a-S1-Cu1 & $130.97(7)$ & &
\end{tabular}




\subsection{Crystal structure of 2,3-pyrazinedithiol ( $\mathrm{H}_{2} \mathrm{pdt}$ )}

As mentioned in the introduction, a crystal structure analysis of $\mathrm{H}_{2} \mathrm{pdt}$ was performed in order to determine the tautomeric form in the solid state. Single crystals were obtained by heating a suspension of $\mathrm{H}_{2} \mathrm{pdt}$ in methanol in a sealed microwave vessel to $100^{\circ} \mathrm{C}$, without stirring. After $2 \mathrm{~h}$ of heating, the vessel was cooled down to room temperature with compressed air, and red needles were isolated. $\mathrm{H}_{2}$ pdt crystallizes in space group $P 2_{1} / c$ with $Z=4$. Hydrogen atoms were refined freely on N1 and N2 because of significant electron density on expected positions. Further evidence for the $\mathrm{N}-\mathrm{H}$ tautomeric form are the short C-S bond lengths of 167.7(2) and 166.5(2) pm (Table SI-6) that correspond to typical $\mathrm{C}-\mathrm{S}$ double bond lengths. ${ }^{10} \mathrm{It}$ is also noteworthy that the bond distances in the protonated pyrazine ring differ in a wider range than in aromatic systems and C3-C4 (134.1(3) pm) is considerably shorter than C1-C2 (148.2(3) pm). The molecules are regularly stacked in a direction with a distance of $335.5(2)-340.6(2) \mathrm{pm}$. The tilt angle of about $31^{\circ}$ between a least square plane spanned by the molecule and the stacking axis is causing the molecules to arrange in a "staircase" structure (Figure SI5 , right). Both $\mathrm{NH}$ hydrogen atoms are involved in hydrogen bonds towards $\mathrm{S} 1$ atoms of two adjacent molecules ( $\mathrm{N} 1-\mathrm{H} 1 \cdots \mathrm{S} 1 \mathrm{a}=326.6(2) \mathrm{pm}, \mathrm{N} 2-\mathrm{H} 2 \cdots \mathrm{S} 1 \mathrm{~b}=334.8(2) \mathrm{pm})$, to form a two-dimensional network, perpendicular to the stacking axis (Figure $\mathrm{SI}-6$ ).
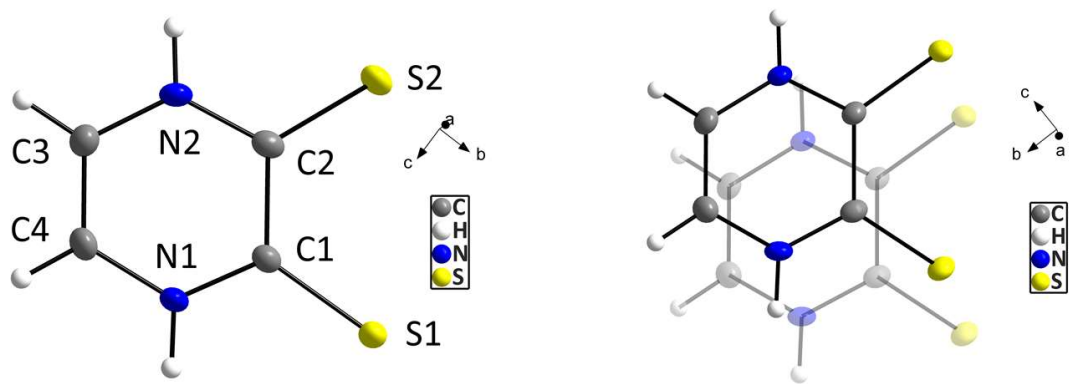

Figure SI-5: Ellipsoid representation ( $50 \%$ ) of $\mathrm{H}_{2}$ pdt (left) and depiction of the offset stacking of $\mathrm{H}_{2}$ pdt molecules (right). The viewing direction is perpendicular to the molecular plane.

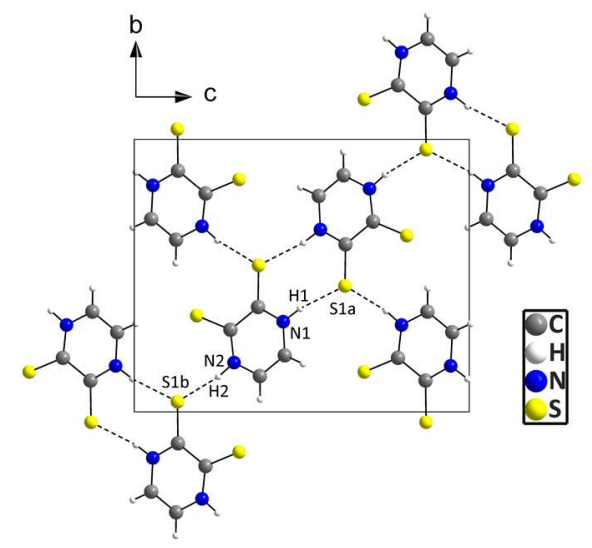

Figure SI-6: Ball and stick representation of the packed $\mathrm{H}_{2}$ pdt molecules with hydrogen bonds in a two-dimensional network perpendicular to the $a$ axis. Symmetry codes: a (1-x, 1-y, 1-z), b (2-x, -0.5+y, 0.5-z).

Table SI-6: Bond lengths in $\mathrm{H}_{2}$ pdt.

\begin{tabular}{llll} 
Bond & Distance in pm & Bond & Distance in pm \\
\hline C1-S1 & $167.7(2)$ & C1-N1 & $134.3(3)$ \\
C2-S2 & $166.5(2)$ & C2-N2 & $134.4(3)$ \\
C1-C2 & $148.2(3)$ & C4-N1 & $137.3(3)$ \\
C3-C4 & $134.1(3)$ & C3-N2 & $137.3(3)$
\end{tabular}




\subsection{Crystal structure of $\left[\mathrm{Cu}\left(\mathrm{H}_{2} \mathrm{pdt}\right)_{2}\right] \mathrm{Cl}\left(1^{\prime}\right)$}

As indicated by the PXRD analysis of $\left[\mathrm{Cu}\left(\mathrm{H}_{2} \mathrm{pdt}\right)_{2}\right] \mathrm{Cl}$ (Figure $\mathrm{SI}-2$ ), the compound crystallizes in two different crystal structures. Layering a methanolic solution with diethyl ether yielded single crystals of the monoclinic form (1) described in the main paper, and single crystals of the triclinic form ( $\left.\mathbf{1}^{\prime}\right)$ discussed in the following. Like in the crystal structure of $\mathbf{1}$, the asymmetric unit in $\mathbf{1}^{\prime}$ consists of one copper dithiolene complex cation and the chloride anion. The analysis of the crystal structures reveals a similar molecular structure for the $\left[\mathrm{Cu}\left(\mathrm{H}_{2} \mathrm{pdt}\right)_{2}\right]^{+}$cations in $\mathbf{1}$ and $\mathbf{1}^{\prime}$ and different packing interactions.

Figure SI-7 shows a slightly distorted tetrahedral geometry around the copper atom with the dihedral angle between $\mathrm{S} 1 / \mathrm{Cu} 1 / \mathrm{S} 2$ and $\mathrm{S} 4 / \mathrm{Cu} 1 / \mathrm{S} 3$ being $86.28(2)^{\circ}$. One of the ligands is bent out of the long axis of the complex, described by the torsion angle S3-Cu1-S4-C6 being 11.17(6) ${ }^{\circ}$. The $\mathrm{Cu}-\mathrm{S}$ distances are in the range of 226.51(5) pm to 232.97(5) pm. Three hydrogen bonds of $\mathrm{H} 1, \mathrm{H} 2$, and $\mathrm{H} 4$ to chloride ions with $\mathrm{N}-\mathrm{H} \cdots \mathrm{Cl}$ donor $\cdots$ acceptor distances ranging from 302.0(1) to 312.9(1) pm (Figure SI-7 and Table SI-8) engender a columnar arrangement of the dithiolene cations, as it is shown in Figure SI-8. The columns consist of two stacks of dithiolene complexes oriented in $b$ direction. Hydrogen bonds via $\mathrm{H} 1$ and $\mathrm{H} 2$ connect complexes that belong to one stack, and hydrogen bonds involving $\mathrm{H} 4$ connect the two stacks to one column. Neighbouring columns in a direction are further linked into a twodimensional network via weak offset $\pi \cdots \pi$ stacking interactions of about $376.6(2)-377.5(2) \mathrm{pm}$ and additional $\mathrm{N}-\mathrm{H} \cdots \mathrm{S}$ hydrogen bonds with $\mathrm{N} 3 \cdots \mathrm{S} 1 \mathrm{c}=340.9(1) \mathrm{pm}$ (Figure SI-7 and Figure SI-9).
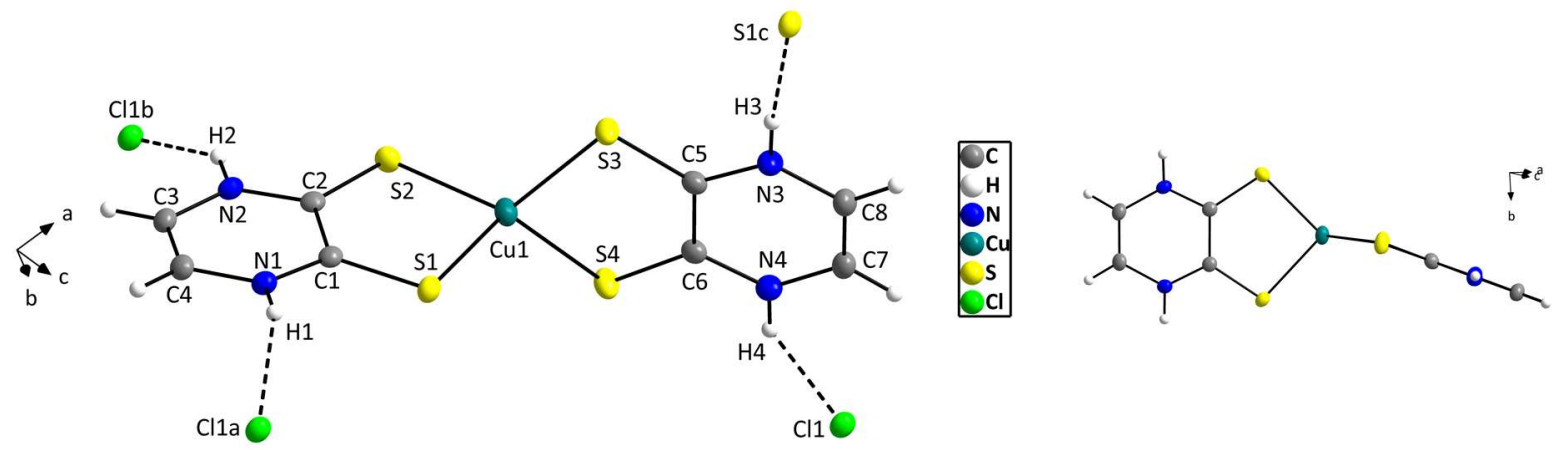

Figure SI-7: Ellipsoid representation $(50 \%)$ of the cation in $\left[\mathrm{Cu}\left(\mathrm{H}_{2} \mathrm{pdt}\right)_{2}\right] \mathrm{Cl}\left(\mathbf{1}^{\prime}\right)$ with $\mathrm{H} \cdots \mathrm{Cl}$ and $\mathrm{H} \cdots \mathrm{S}$ interactions (left) and depiction of the $\left[\mathrm{Cu}\left(\mathrm{H}_{2} \mathrm{pdt}\right)_{2}\right]^{+}$cation with viewing direction along one ligand (right). Symmetry codes: a (1-x, 1-y, 1-z), b (1-x, -y, 1-z), c (1+x, y, z).

Table SI-7: Selected distances (in pm) and bond angles (in $\left.{ }^{\circ}\right)$ in $\left[\mathrm{Cu}\left(\mathrm{H}_{2} \mathrm{pdt}\right)_{2}\right] \mathrm{Cl}\left(\mathbf{1}^{\prime}\right)$.

\section{Cu' coordination}

Cu1-S2

Cu1-S4

Cu1-S3

Cu1-S1

S1-CU1-S2

S3-Cu1-S4

S1-Cu1-S3

S2-Cu1-S4
$\mathrm{H}_{2}$ pdt ligand

$\begin{array}{ll}\text { C1-S1 } & 169.4(2) \\ \text { C2-S2 } & 167.7(2) \\ \text { C5-S3 } & 167.3(2) \\ \text { C6-S4 } & 167.3(2) \\ \text { C1-C2 } & 146.7(2) \\ \text { C5-C6 } & 147.9(2)\end{array}$


Table SI-8: Hydrogen bonds (in pm, ${ }^{\circ}$ ) in 1'. Symmetry codes: a (1-x, 1-y, 1-z), b (1-x, -y, 1-z), c (1+x, y, z).

\begin{tabular}{|c|c|c|c|c|}
\hline$D-H \cdots A$ & $\mathrm{D}-\mathrm{H}$ & $H \cdots A$ & $D \cdots A$ & $D-H \cdots A$ \\
\hline $\mathrm{N} 4-\mathrm{H} 4 \cdots \mathrm{Cl} 1$ & $83(2)$ & $238(2)$ & $312.9(1)$ & $151(2)$ \\
\hline $\mathrm{N} 1-\mathrm{H} 1 \cdots \mathrm{Cl} 1 \mathrm{a}$ & $86(2)$ & $222(2)$ & $302.0(1)$ & $156(2)$ \\
\hline $\mathrm{N} 2-\mathrm{H} 2 \cdots \mathrm{Cl} 1 \mathrm{~b}$ & $77(2)$ & 236(3) & $304.6(2)$ & $150(2)$ \\
\hline 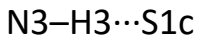 & $82(2)$ & $260(2)$ & $340.9(1)$ & $171(2)$ \\
\hline
\end{tabular}
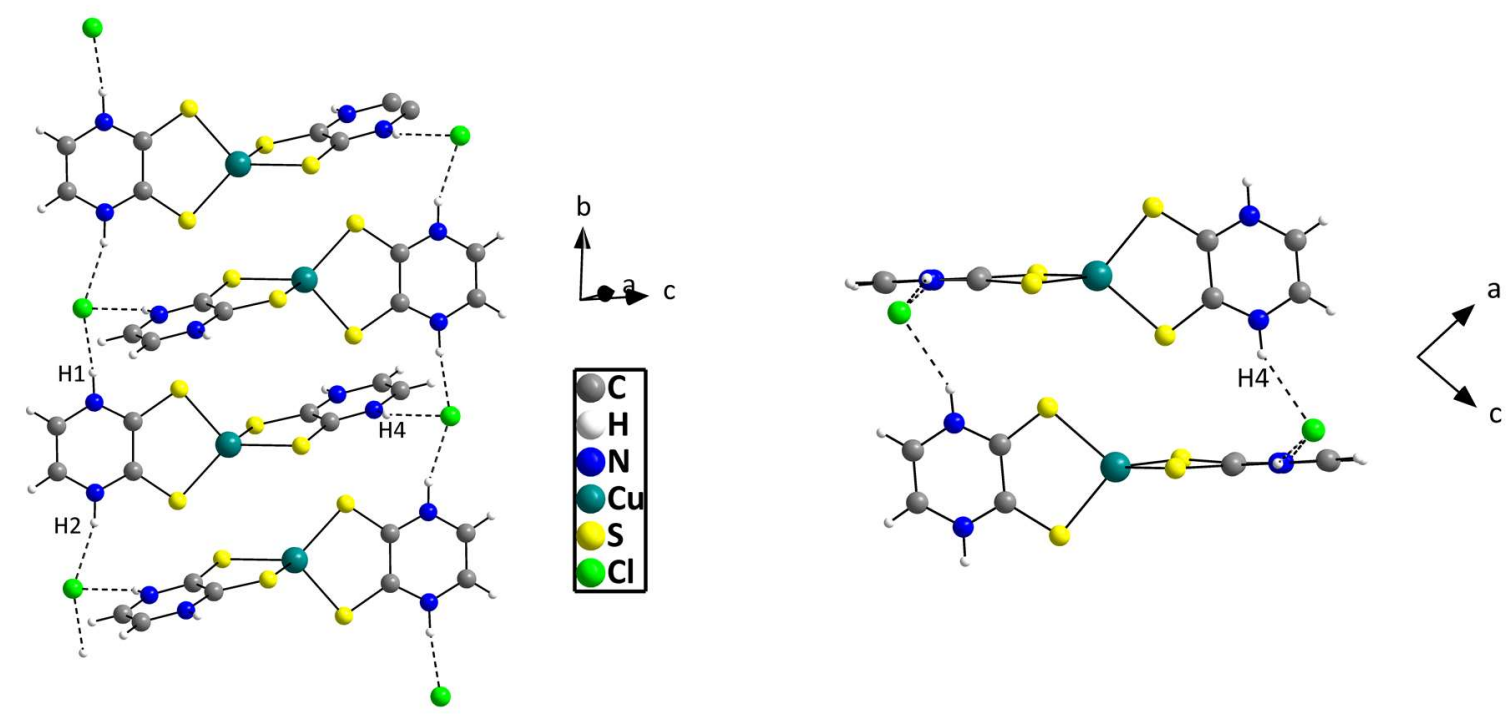

Figure SI-8: Ball and stick representation of the columnar arrangement of $\left[\mathrm{Cu}\left(\mathrm{H}_{2} \mathrm{pdt}\right)_{2}\right]^{+}$cations in $\mathbf{1}^{\prime}$ via $\mathrm{N}-\mathrm{H} \cdots \mathrm{Cl}$ hydrogen bonds. The view is perpendicular (left) and parallel to the stacking direction (right).

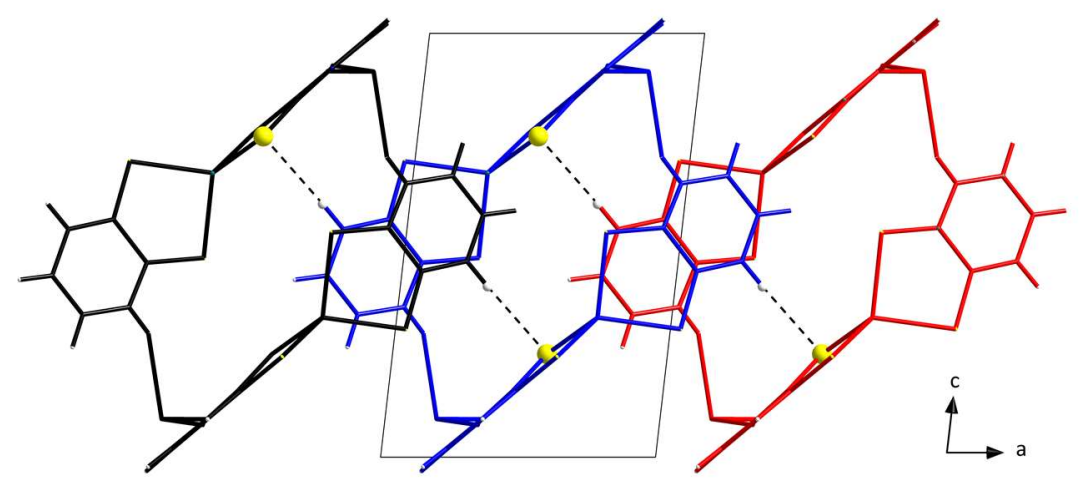

Figure SI-9: Two-dimensional network of adjacent columns via $\mathrm{N}-\mathrm{H} \cdots \mathrm{S}$ hydrogen bonds and $\pi \cdots \pi$ stacking. 


\section{Rietveld refinement of ${ }^{1 D}\left[\mathrm{Cu}_{2} \mathrm{I}_{2}\left(\mathrm{H}_{2} \mathrm{pdt}\right)(\mathrm{Hpdt})\right](5)$}

The PXRD analysis of ${ }^{1 D}\left[\mathrm{Cu}_{2} \mathrm{l}_{2}\left(\mathrm{H}_{2} \mathrm{pdt}\right)(\mathrm{Hpdt})\right](5)$ is based on a room temperature measurement of a sample of ${ }^{1 \mathrm{D}}\left[\mathrm{Cu}\left(\mathrm{H}_{2} \mathrm{pdt}\right) \mathrm{I}\right](4)$ in a glass capillary after heating to $230^{\circ} \mathrm{C}$. The diffraction pattern was indexed and the structure was solved with EXPO2014, ${ }^{11}$ using the simulated annealing solution method. Rietveld refinement was performed with TOPAS. ${ }^{12}$ The ligands $\mathrm{H}_{2} \mathrm{pdt}$ and $\mathrm{Hpdt}^{-}$were defined as rigid bodies using the z-matrix notation. Atomic positions of the copper and iodine ions were not restrained during the refinement.

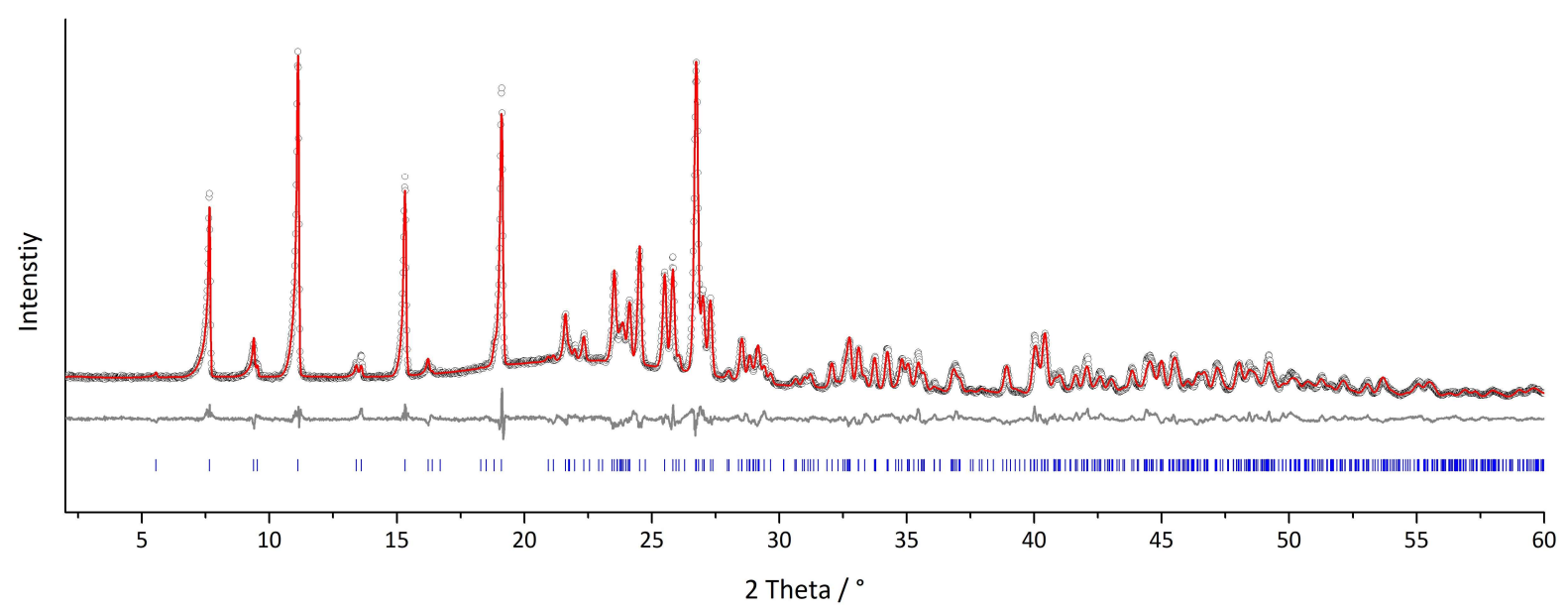

Figure SI-10: Rietveld refinement of PXRD data of ${ }^{1 D}\left[\mathrm{Cu}_{2} \mathrm{l}_{2}\left(\mathrm{H}_{2} \mathrm{pdt}\right)(\mathrm{Hpdt})\right]$ (5). Observed (black), calculated (red) and difference (grey) profiles as a function of diffraction angle $2 \Theta ; R_{w p}=4.65, R_{p}=3.53$.

Table SI-9: Selected distances (in pm) and angles (in $\left.{ }^{\circ}\right)$ in ${ }^{1 D}\left[\mathrm{Cu}_{2} \mathrm{I}_{2}\left(\mathrm{H}_{2} \mathrm{pdt}\right)(\mathrm{Hpdt})\right](5)$. Symmetry codes: a $(-1+x, 1+y, z), b(1+x$, $y, z)$.

Cu1 coordination

\section{Cu1-I1}

Cu1-I1b

Cu1-12

Cu1-S3

I1-Cu1-I2

I1-Cu1-S3

I1-Cu1-I1b

S3-Cu1-12

S3-Cu1-I1b

I1b-Cu1-12
Cu2 coordination

$\begin{array}{lll}281(1) & \text { Cu2-S1 } & 235(2) \\ 250(1) & \text { Cu2-S2 } & 233(4) \\ 259(1) & \text { Cu2-S3 } & 235(2) \\ 228(2) & \text { Cu2-S4 } & 232(4) \\ 106.0(4) & \text { S1-Cu2-S2 } & 87.5(7) \\ 101.8(7) & \text { S3-Cu2-S4 } & 87.9(7) \\ 107.9(5) & \text { S1-Cu2-S3 } & 177.2(8) \\ 114.9(6) & \text { S2-Cu2-S4 } & 176(1)\end{array}$

117.3(7)

108.1(4) 


\section{DFT and TD-DFT simulations}

The structure of the $\left[\mathrm{Cu}\left(\mathrm{H}_{2} \mathrm{pdt}\right)_{2}\right]^{+}$cation with idealized $\mathrm{D}_{2 \mathrm{~d}}$ symmetry was optimized by DFT calculations with the $\mathrm{PBEO}^{13}$ hybrid functional, using native Slater-type orbitals with triple zeta quality and one polarization function (TZP) ${ }^{14}$ including scalar relativistic corrections and "good" numerical quality as implemented in AMS..$^{15,16}$ TD-DFT calculations were performed with the optimized structure. In order to account for solvent effects, the conductor like screening model COSMO, ${ }^{17,18}$ representing the solvent (methanol) as a dielectric polarizable continuum, was applied. All allowed excitations in the Davidson procedure were calculated.

Table SI-10: Allowed excitations of $\left[\mathrm{Cu}\left(\mathrm{H}_{2} \mathrm{pdt}\right)_{2}\right]^{+}$in methanol, simulated by TD-DFT.

\begin{tabular}{llll}
$\begin{array}{l}\text { Transition } \\
\text { in } \mathbf{n m}\end{array}$ & $\begin{array}{l}\text { Oscillator } \\
\text { Strength }\end{array}$ & $\begin{array}{l}\text { Nature } \\
\text { (transition contribution in \%) }\end{array}$ & Type of transition \\
\hline 369 & 0.029 & HOMO-1 -> LUMO+2 (88 \%) & MLCT \\
373 & 0.026 & HOMO -> LUMO+2 (92\%) & MLCT \\
375 & 0.366 & HOMO-4 -> LUMO(61 \%) & $\pi->\pi^{*}$, MLCT \\
410 & 0.014 & HOMO-2 -> LUMO+1 (95\%) & MLCT \\
410 & 0.015 & HOMO-2 -> LUMO (94\%) & MLCT \\
626 & 0.594 & HOMO -> LUMO (99\%) & MLCT
\end{tabular}

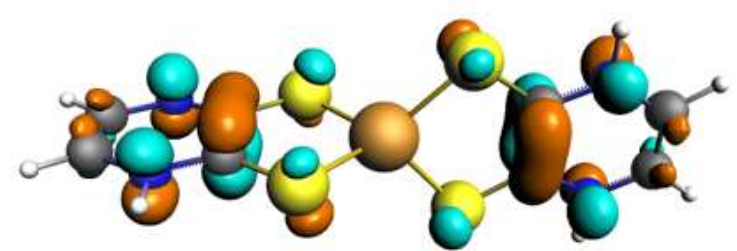

LUMO

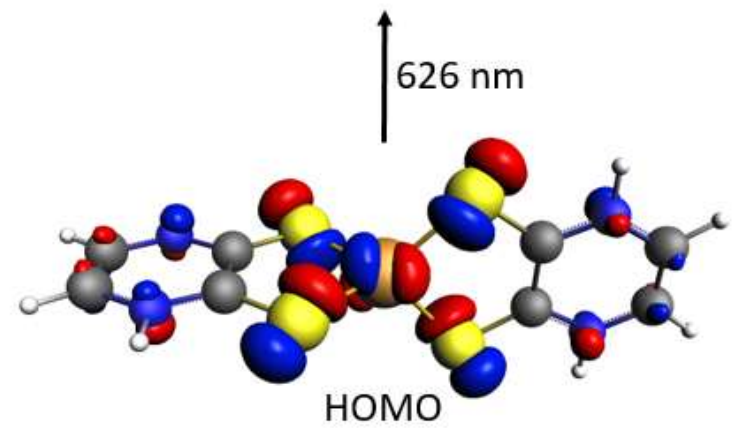

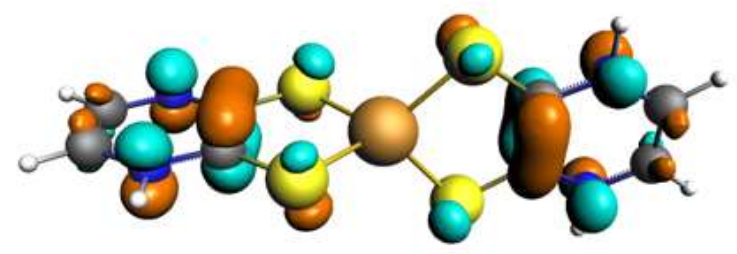

LUMO

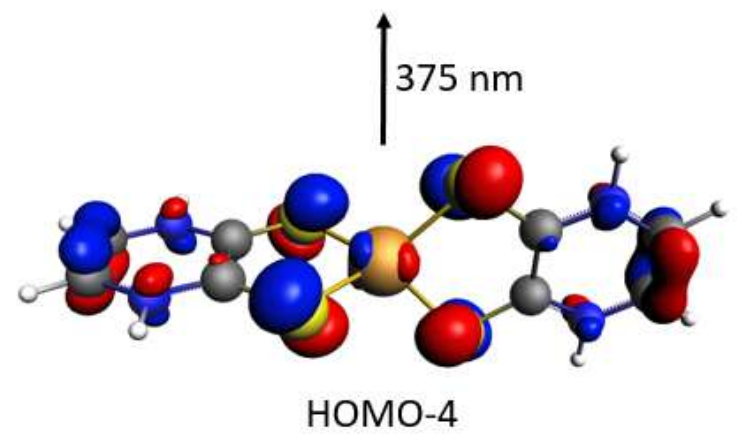

Figure SI-11: Orbital representation of the two strongest UV-Vis excitations. Occupied orbitals are shown in blue and red, unoccupied orbitals are presented in orange and cyan to indicate the sign of the radial part of the wave function, respectively. 


\section{UV-Vis-NIR spectroscopy}

Since the solutions of compounds $\mathbf{1}$ and $\mathbf{3}$ were found to be air sensitive, they were not prepared in volumetric flasks, but in Schlenk tubes, by adding a specific volume of solvent for the desired dilution. The solution absorption spectra were collected on a Jasco V-670 UV-Vis-NIR spectrophotometer. Since the first oxidation step of $\mathbf{1}$ in DMSO upon air exposure was found to occur rather quickly (within several minutes) in a standard $1 \mathrm{~cm}$ quartz cell, the process was investigated using a $0.1 \mathrm{~cm}$ quartz cell with stopcock and a sample concentration of $7.3 \cdot 10^{-4} \mathrm{~mol} / \mathrm{L}$. The representation of the second oxidation process is derived from a measurement with a $1 \mathrm{~cm}$ quartz cell and a sample concentration of $2.1 \cdot 10^{-5} \mathrm{~mol} / \mathrm{L}$.

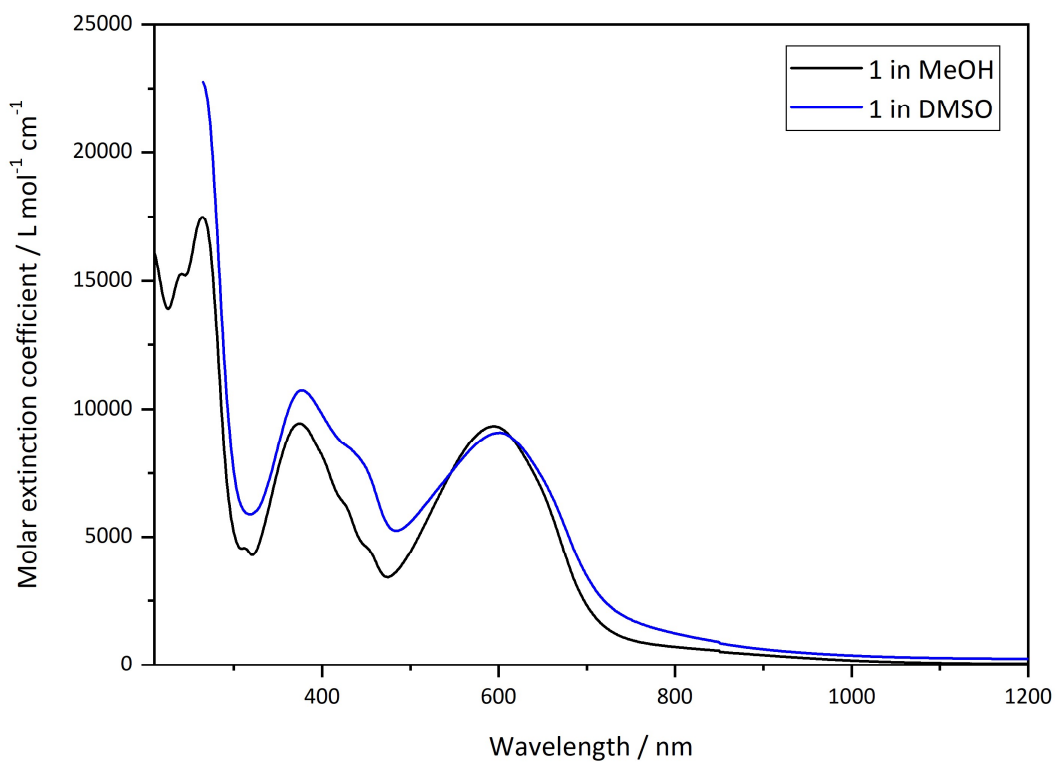

Figure SI-12: UV-Vis-NIR absorption spectra of 1 in methanol and DMSO.

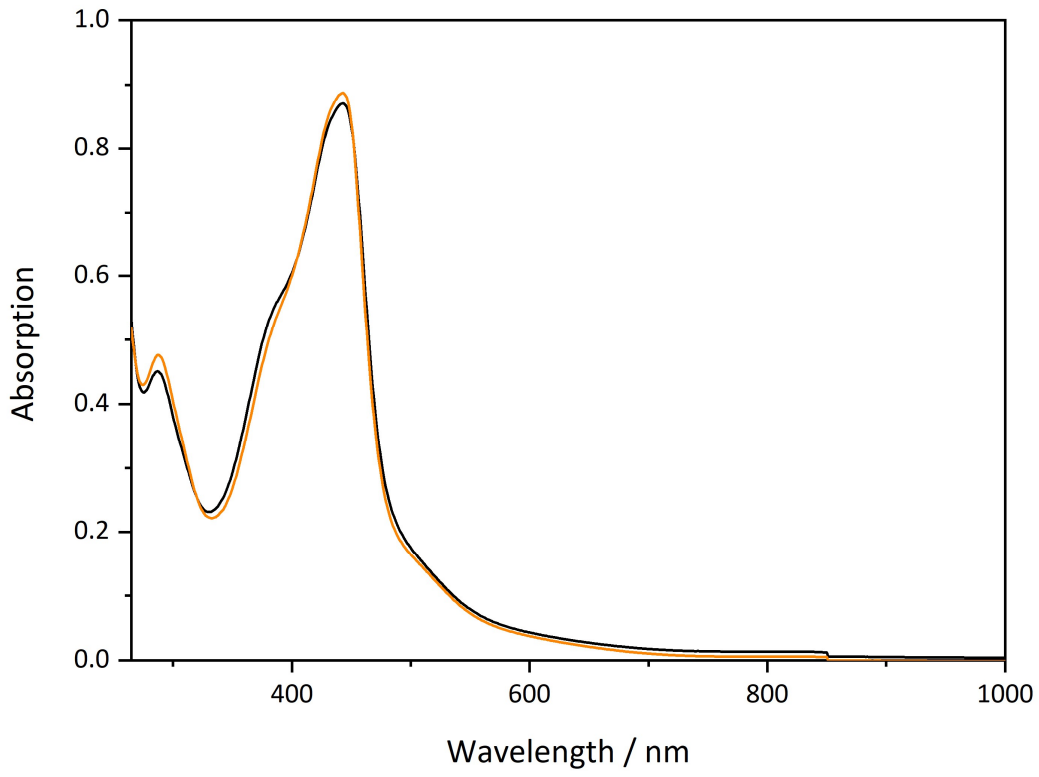

Figure SI-13: UV-Vis-NIR absorption spectra of 1 after the first oxidation process (orange) and of $\mathbf{3}$ (black). 


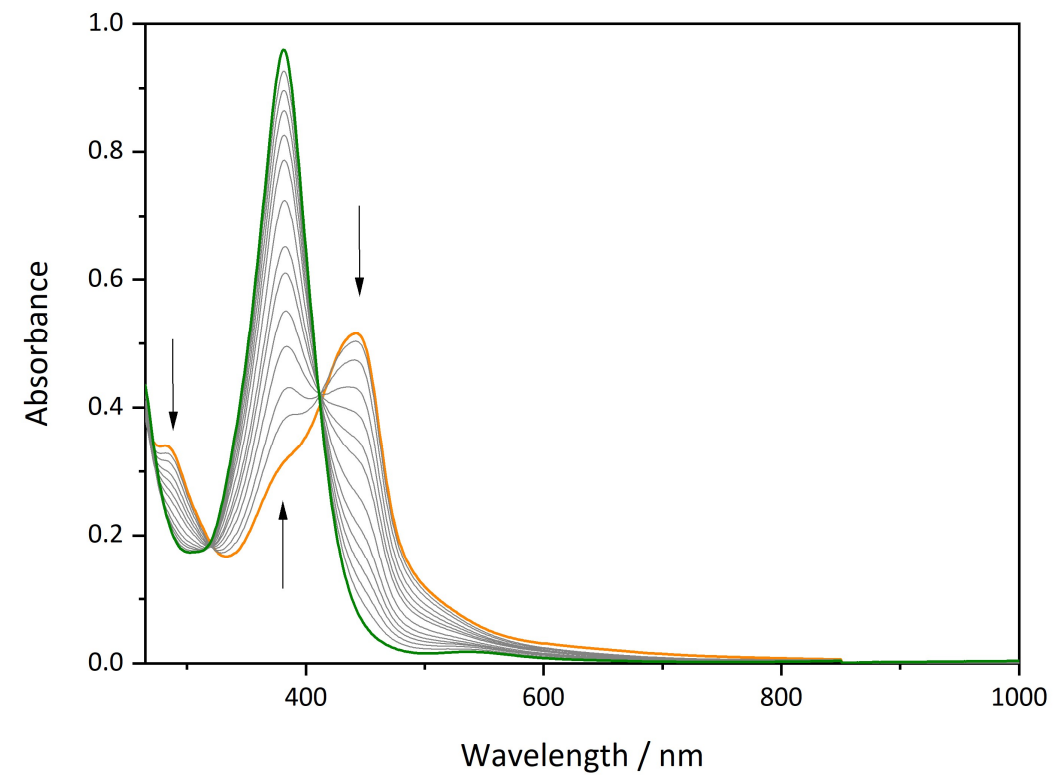

Figure SI-14: Photometric response of a second oxidation process of 1 in DMSO before (orange) and after (green) further air exposure for $120 \mathrm{~min}$.

\section{Cyclic voltammetry}

The cyclic voltammetry studies were performed with a SP-150 VMP3 potentiostat from BioLogic. Samples were characterized in a $0.1 \mathrm{M}\left(\mathrm{Bu}_{4} \mathrm{~N}\right) \mathrm{PF}_{6}$ DMSO solution at a platinum disc working electrode (1.6 $\mathrm{mm}$ diameter) with a platinum wire counter electrode, both polished with $0.05 \mu \mathrm{m}$ alumina paste and electrochemically cleaned in a $1.8 \mathrm{M} \mathrm{H}_{2} \mathrm{SO}_{4}$ solution. As reference electrode a silver wire in a $0.01 \mathrm{M} \mathrm{AgNO}_{3}$ and $0.1 \mathrm{M}\left(\mathrm{Bu}_{4} N\right) \mathrm{PF}_{6}$ acetonitrile solution was used. The electrolyte $\left(\mathrm{Bu}_{4} \mathrm{~N}\right) \mathrm{PF}_{6}$ was recrystallized in ethanol and dried under reduced pressure at $100{ }^{\circ} \mathrm{C}$. Before each measurement the filled single compartment cell was degassed with nitrogen for ten minutes. After the sample measurements, the voltammograms are internally referenced using the ferrocene/ferrocenium $\left(\mathrm{Fc} / \mathrm{Fc}^{+}\right)$redox couple.

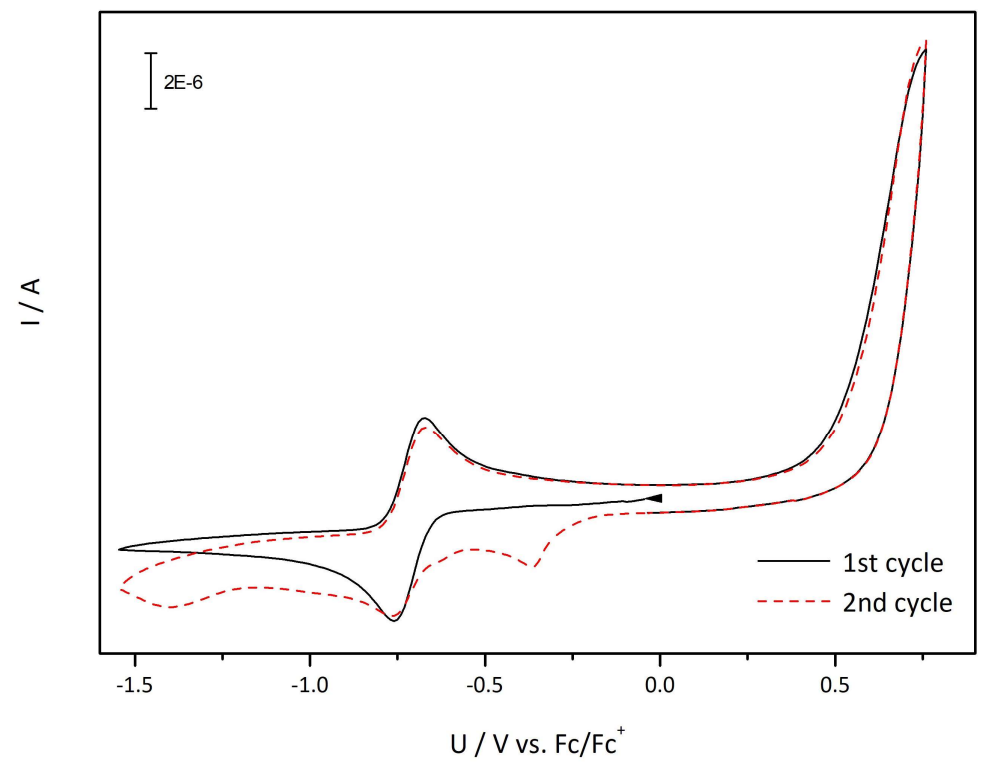

Figure SI-15: Two cycle scan of $\left(\mathrm{Bu}_{4} \mathrm{~N}\right)\left[\mathrm{Cu}(\mathrm{pdt})_{2}\right]$ between -1.5 and $0.75 \mathrm{~V} \mathrm{vs}$. $\mathrm{Fc} / \mathrm{Fc}^{+}$in $\mathrm{DMSO}$ at v $=50 \mathrm{mV} \cdot \mathrm{s}^{-1}$. 


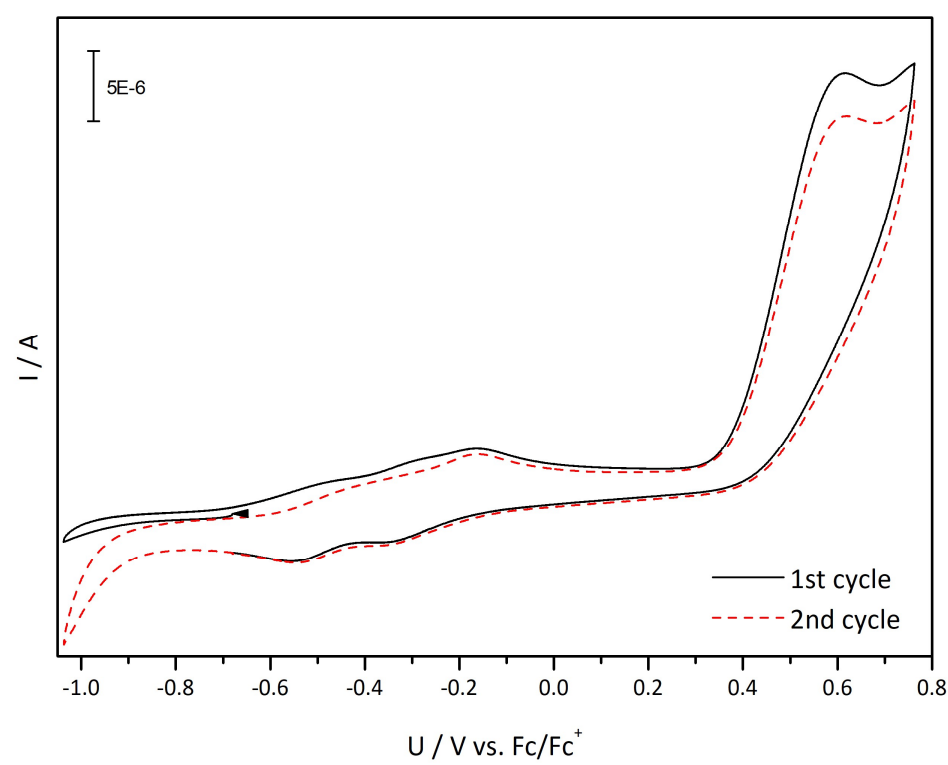

Figure SI-16: Two cycle scan of $\left[\mathrm{Cu}\left(\mathrm{H}_{2} \mathrm{pdt}\right)_{2}\right] \mathrm{Cl}(\mathbf{1})$ between -1.0 and $0.8 \mathrm{~V} \mathrm{vs}$. $\mathrm{Fc} / \mathrm{Fc}^{+}$in $\mathrm{DMSO}$ at $\mathrm{v}=100 \mathrm{mV} \cdot \mathrm{s}^{-1}$.

\section{Magnetic characterization of 3}

The paramagnetic complex $\left[\mathrm{Cu}(\mathrm{Hpdt})_{2}\right](3)$ was characterized by a temperature dependent magnetic susceptibility measurement between 2 and $300 \mathrm{~K}$ in an applied external field of $0.5 \mathrm{~T}$ with a MPMS 7XL SQUID magnetometer (Quantum Design). Data processing was performed with OriginPro. ${ }^{19}$

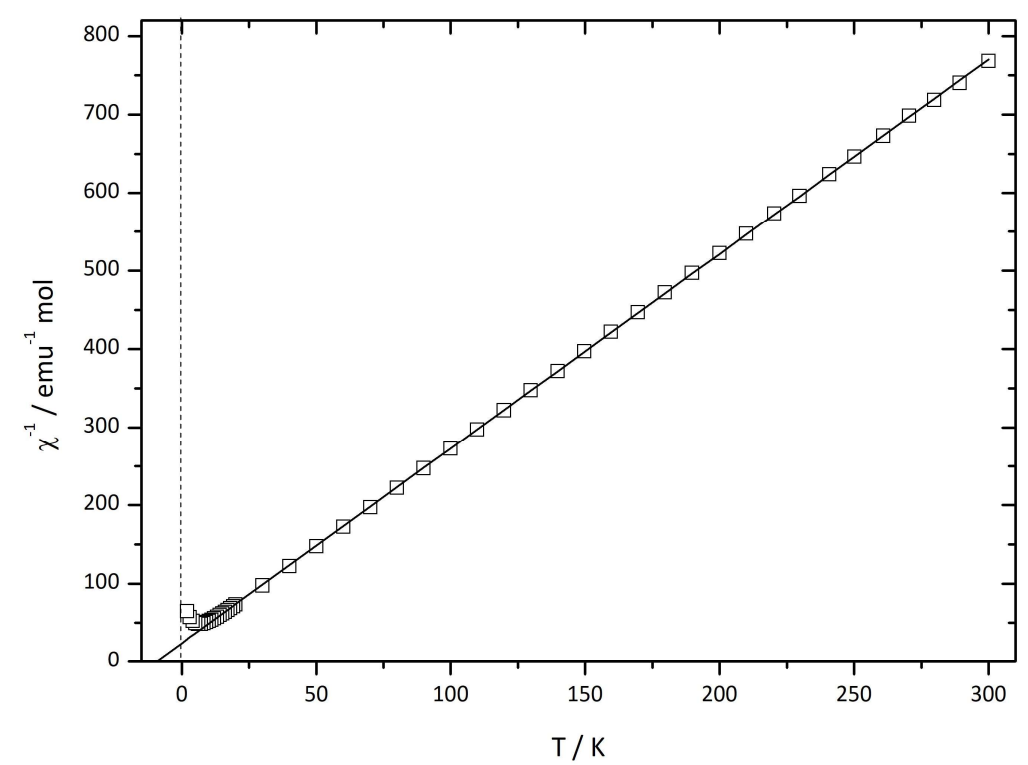

Figure SI-17: Inverse of magnetic susceptibility versus temperature with Curie-Weiss fit to the data in the temperature range of $13-300 \mathrm{~K}$. 


\section{Conductivity measurements}

Electrical conductivity was investigated via two-point direct current (dc)-conductivity measurements performed on pressed pellets within the Ohmic regime. Temperature dependence was measured from 300 to $373 \mathrm{~K}$. Data processing was performed with OriginPro. ${ }^{19}$

The activation energy $E_{a}$ was determined by fitting the temperature dependent conductivity to the Arrhenius model, where $\sigma$ is the conductivity and $\sigma_{0}$ a prefactor (Eq. (1)). The activation energy is a measure of how easy charge carriers can be excited, provided that the charge mobility is constant in the examined temperature range. It is further strongly dependent on the level of doping or impurity. ${ }^{20}$

$$
\sigma=\sigma_{0} \cdot \exp \left(-\frac{E_{a}}{k_{B} T}\right)
$$

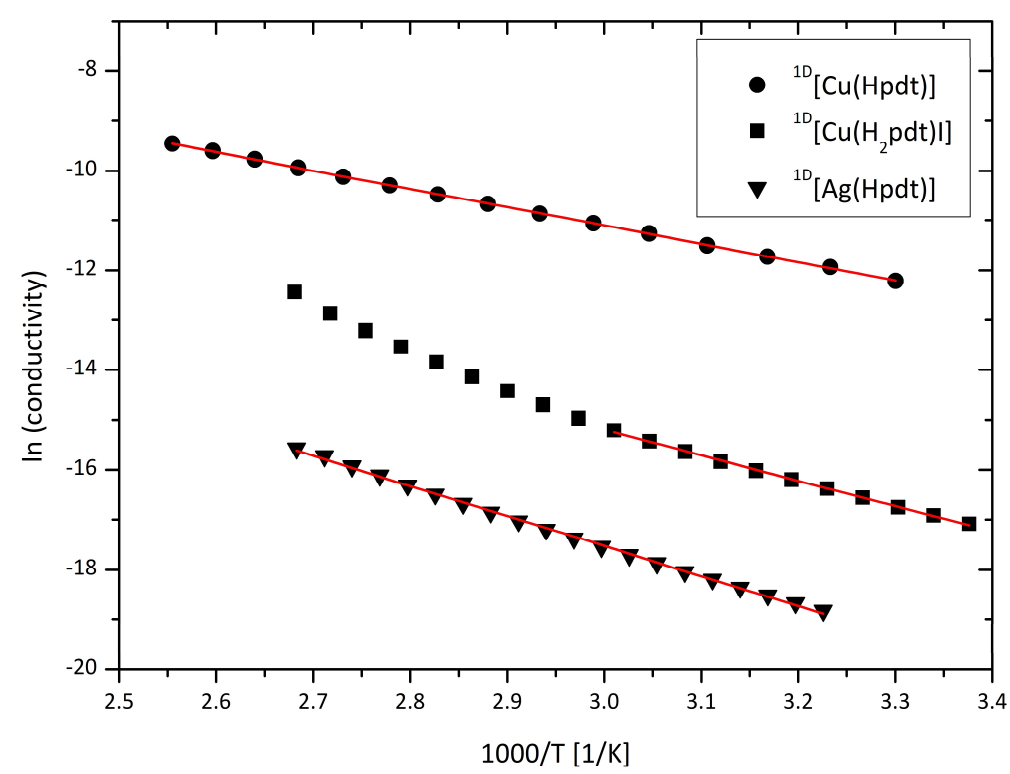

Figure SI-18: Temperature dependence of the electrical conductivity of ${ }^{1 D}[\mathrm{Cu}(\mathrm{Hpdt})]\left(2^{\mathrm{Cu}}\right)$ (circles), ${ }^{1 \mathrm{D}}\left[\mathrm{Cu}\left(\mathrm{H}_{2} \mathrm{pdt}\right) \mathrm{I}\right](4)$ (squares), and ${ }^{1} \mathrm{D}[\mathrm{Ag}(\mathrm{Hpdt})]\left(\mathbf{2}^{\mathrm{Ag}}\right)$ (triangles). The red lines show the fit to the Arrhenius model (in case of $\mathbf{4}$ in the temperature range 20$\left.60^{\circ} \mathrm{C}\right)$. 


\section{Diffuse reflectance spectroscopy}

Diffuse reflectance spectra were collected on a Jasco V-670 UV-Vis-NIR spectrophotometer equipped with an ARN-914 absolute reflectance measurement unit, a photomultiplier and a $\mathrm{PbS}$ photoconductive cell. Because of its strong absorbance, the sample of 4 was optically diluted with $\mathrm{BaSO}_{4}\left(4 / \mathrm{BaSO}_{4}, 1: 10, \mathrm{~m} / \mathrm{m}\right)$. Data processing was performed with OriginPro. ${ }^{19}$

The diffuse reflectance $R$ of a sample is related to the absorption coefficient $K$ and its scattering coefficient $S$ via the Kubelka-Munk function: ${ }^{21}$

$$
F_{K M}=\frac{(1-R)^{2}}{2 R}=\frac{K}{S}
$$

Assuming the scattering coefficient being independent from the wavelength, $F_{K M}$ is directly proportional to the absorption of a sample.

The determination of band gap values via Tauc plots was introduced by J. Tauc and further developed by Davis and Mott. ${ }^{22-25}$ They showed that the optical absorption is linked to the difference between the photon Energy $(h v)$ and the optical band gap $E_{g, \text { opt }}$ via the relation (3) and $\eta=1 / 2,3 / 2,2$, or 3 for direct allowed, direct forbidden, indirect allowed, and indirect forbidden transitions. The values for $E_{g, o p t}$ are obtained by extrapolating the linear region of a $(K \cdot h v)^{1 / \eta} v s . h v$ plot to the abscissa.

$$
(K \cdot h v)^{\frac{1}{\eta}} \propto h v-E_{g, o p t}
$$
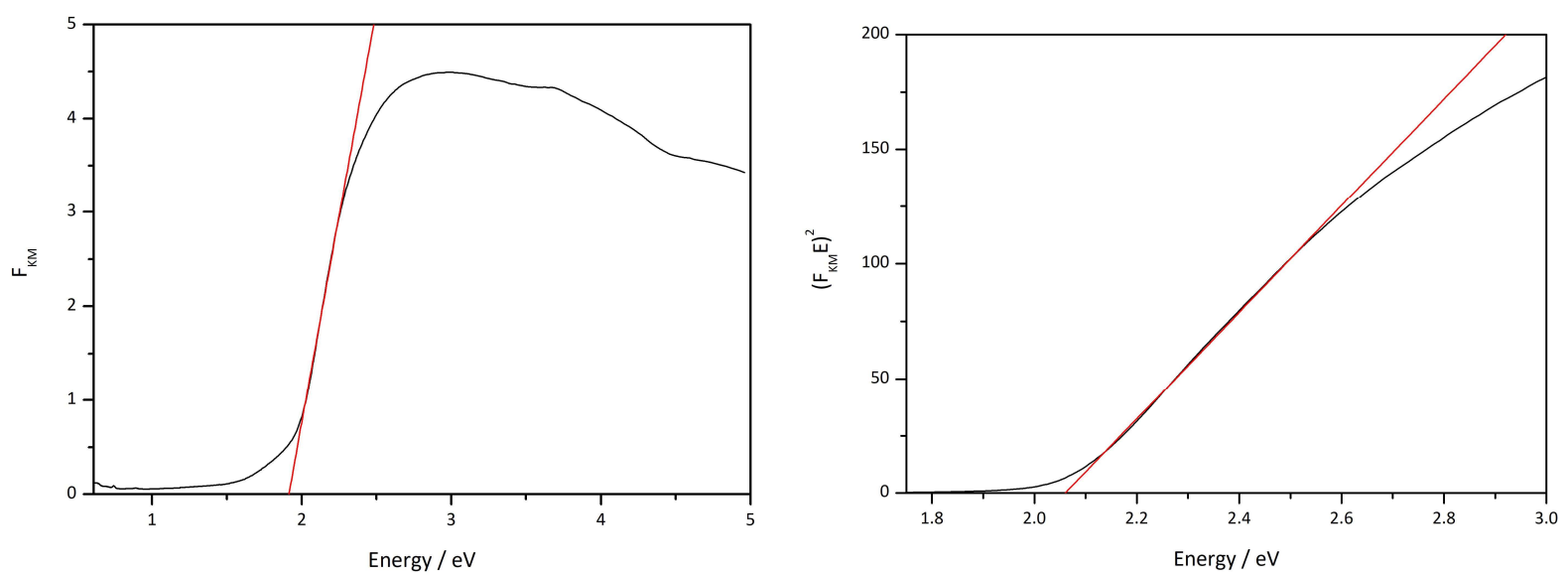

Figure SI-19: Kubelka-Munk converted diffuse reflectance spectrum of $2^{\mathrm{Ag}}$ (left) and Tauc plot for direct allowed transition, $\eta=1 / 2$ (right). The red lines represent the extrapolation of the linear regions to the abscissa. 

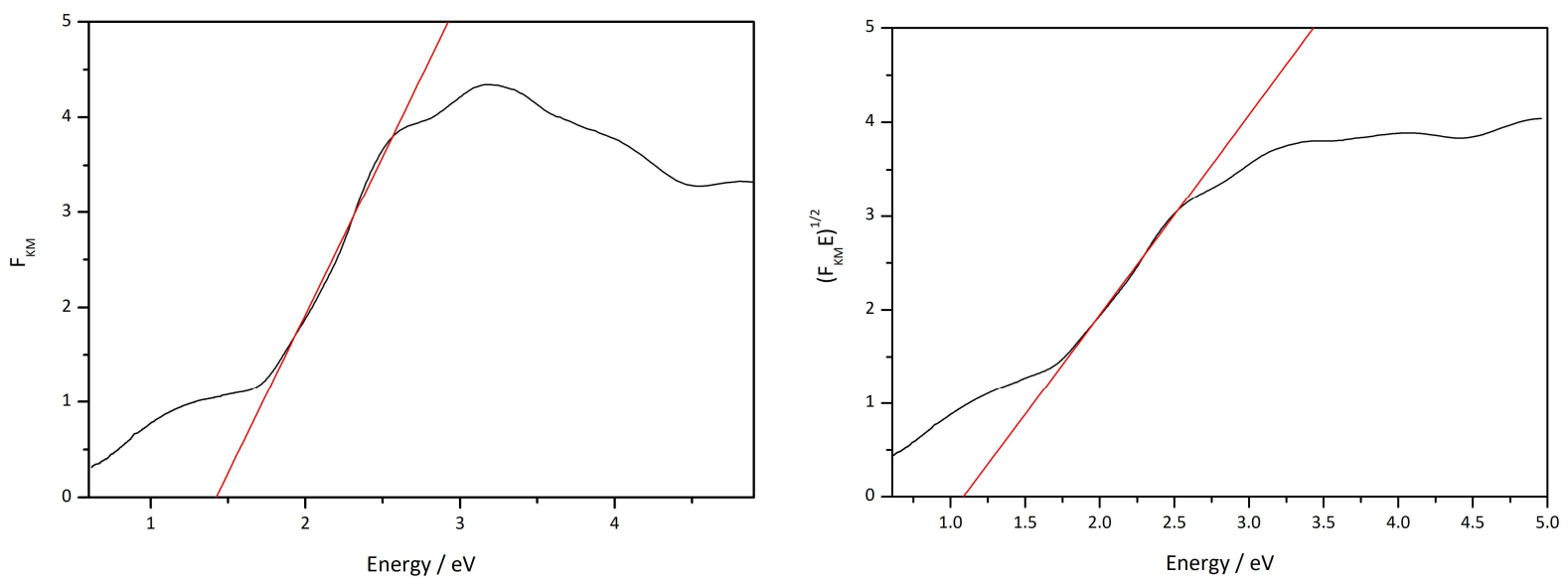

Figure SI-20: Kubelka-Munk converted diffuse reflectance spectrum of $2^{\mathrm{Cu}}$ (left) and Tauc plot for indirect allowed transition, $\eta=2$ (right). The red lines represent the extrapolation of the linear regions to the abscissa.
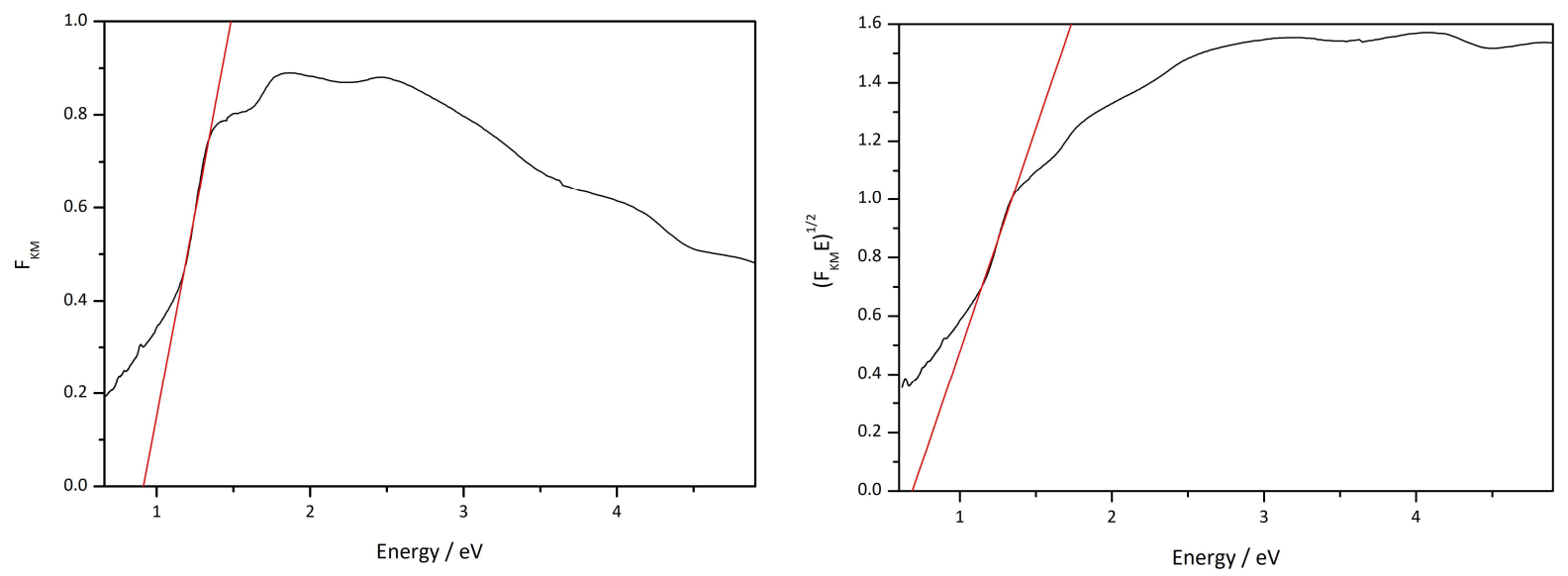

Figure SI-21: Kubelka-Munk converted diffuse reflectance spectrum of 4 (left) and Tauc plot for indirect allowed transition, $\eta=2$ (right). The red lines represent the extrapolation of the linear regions to the abscissa. 


\section{Band structure and DOS calculations}

DFT calculations were performed employing numeric atom-centered atomic orbitals as implemented in FHI-AIMS. ${ }^{26}$ Band structure and density of states calculations were performed on experimental crystal structures with tight tier 2 basis sets using the HSE06 functional on a $6 \times 6 \times 6$ k-grid, including full treatment of relativistic effects through the Zeroth Order Regular Approximation (ZORA) and spin-orbit coupling (SOC). The band structure and DOS calculations of $\mathbf{2}^{\mathrm{Ag}}$ were performed on a simplified structure model in $P 2_{1}$, in which the hydrogen atoms have not been described as disordered.

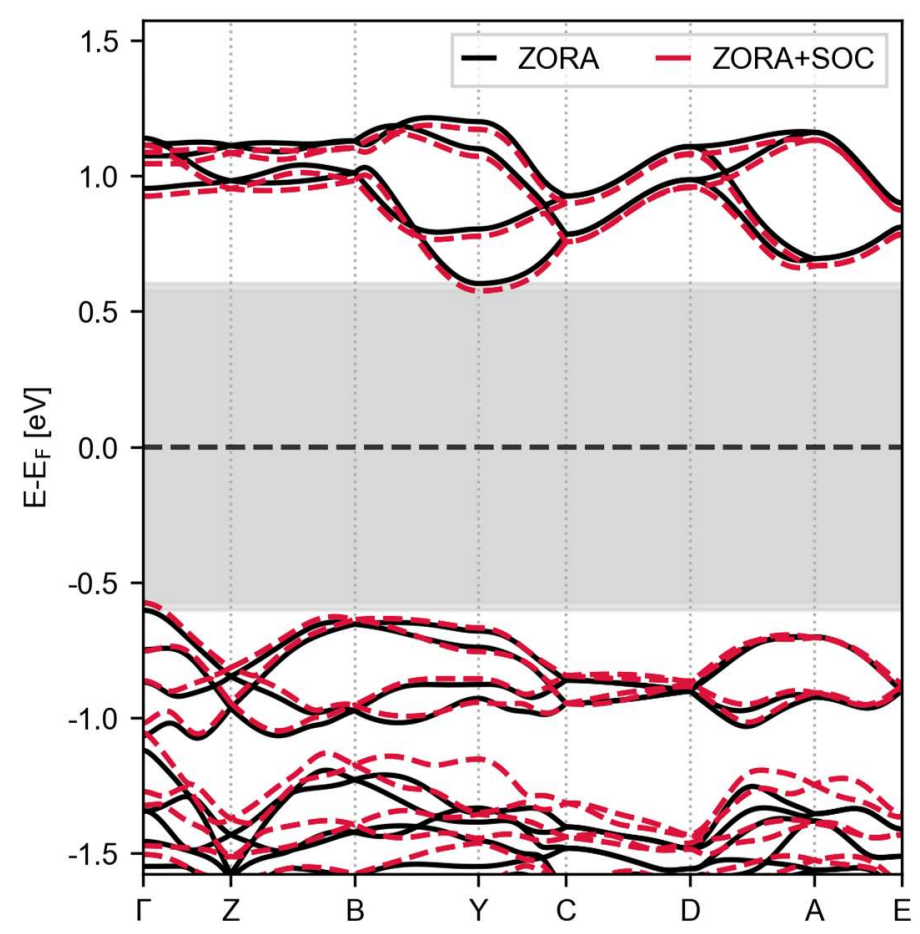

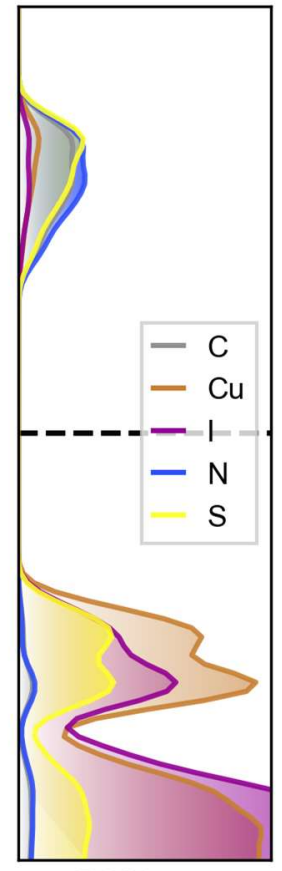

DOS/atom

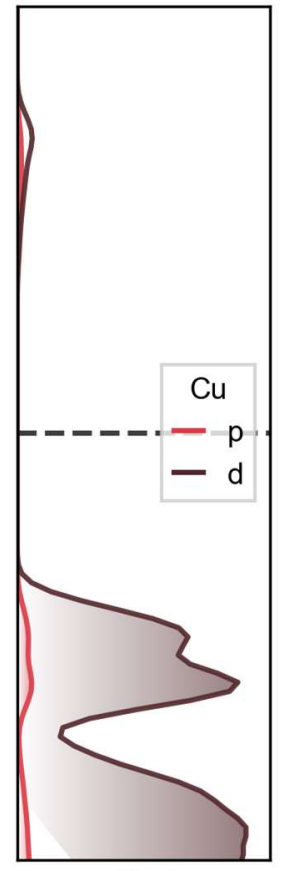

pDOS

Figure SI-22: Band structure and projected DOS of ${ }^{10}\left[\mathrm{Cu}\left(\mathrm{H}_{2} \mathrm{pdt}\right) \mathrm{l}\right](4)$. 


\section{References}

(1) Kobayashi, Y.; Jacobs, B.; Allendorf, M. D.; Long, J. R. Conductivity, Doping, and Redox Chemistry of a Microporous Dithiolene-Based Metal-Organic Framework. Chem. Mater. 2010, 22, 41204122.

(2) Ribas, X.; Dias, J. C.; Morgado, J.; Wurst, K.; Molins, E.; Ruiz, E.; Almeida, M.; Veciana, J.; Rovira, C. Novel Cull' bis-1,2-dichalcogenene complexes with tunable 3D framework through alkaline cation coordination: a structural and theoretical study. Chem. Eur. J. 2004, 10, 1691-1704.

(3) Kennedy, S. R.; Kozar, M. N.; Yennawar, H. P.; Lear, B. J. Synthesis and characterization of the gold dithiolene monoanion, $\left(\mathrm{Bu}_{4} \mathrm{~N}\right)\left[\mathrm{Au}(\mathrm{pdt}=2,3 \text {-pyrazinedithiol })_{2}\right]$. Polyhedron 2016, 103, 100-104.

(4) STOE \& Cie GmbH. X-Area; STOE \& Cie GmbH: Darmstadt, 2018.

(5) Sheldrick, G. M. Crystal structure refinement with SHELXL. Acta Crystallogr., Sect. C: Cryst. Struct. Commun. 2015, 71, 3-8.

(6) Sheldrick, G. M. SHELX; Goettingen, 2014.

(7) Louis J. Farrugia. WinGX; Dept. of Chemistry, University of Glasgow: Glasgow, 2018.

(8) Brandenburg, K. Diamond; Crystal Impact GbR: Bonn, 2014.

(9) Spek, A. L. Single-crystal structure validation with the program PLATON. J. Appl. Crystallogr. 2003, $36,7-13$.

(10) Rindorf, G.; Carlsen, L. The crystal and molecular structures of the thiobenzophenone S-oxide and thiobenzophenone. Acta Crystallogr., Sect. B: Struct. Sci 1979, 35, 1179-1182.

(11) Altomare, A.; Cuocci, C.; Giacovazzo, C.; Moliterni, A.; Rizzi, R.; Corriero, N.; Falcicchio, A. EXPO2013 : a kit of tools for phasing crystal structures from powder data. J. Appl. Crystallogr. 2013, 46, 1231-1235.

(12) Bruker AXS. TOPAS; Bruker AXS, 1999-2014.

(13) Adamo, C.; Barone, V. Toward reliable density functional methods without adjustable parameters: The PBE0 model. J. Chem. Phys. 1999, 110, 6158-6170.

(14) van Lenthe, E.; Baerends, E. J. Optimized Slater-type basis sets for the elements 1-118. J. Comput. Chem. 2003, 24, 1142-1156.

(15) R. Rüger, M. Franchini, T. Trnka, A. Yakovlev, P. Philipsen, T. Soini. AMS 2018; SCM.

(16) E.J. Baerends, T. Ziegler, A.J. Atkins, J. Autschbach, O. Baseggio, D. Bashford, A. Bérces, F.M. Bickelhaupt, C. Bo, P.M. Boerrigter, L. Cavallo, C. Daul, D.P. Chong, D.V. Chulhai, L. Deng, R.M. Dickson, J.M. Dieterich, D.E. Ellis, M. van Faassen, L. Fan, T.H. Fischer, C. Fonseca Guerra, M. Franchini, A. Ghysels, A. Giammona, S.J.A. van Gisbergen, A. Goez, A.W. Götz, J.A. Groeneveld, O.V. Gritsenko, M. Grüning, S. Gusarov, F.E. Harris, P. van den Hoek, Z. Hu, C.R. Jacob, H. Jacobsen, L. Jensen, L. Joubert, J.W. Kaminski, G. van Kessel, C. König, F. Kootstra, A. Kovalenko, M.V. Krykunov, E. van Lenthe, D.A. McCormack, A. Michalak, M. Mitoraj, S.M. Morton, J. Neugebauer, V.P. Nicu, L. Noodleman, V.P. Osinga, S. Patchkovskii, M. Pavanello, C.A. Peeples, P.H.T. Philipsen, D. Post, C.C. Pye, H. Ramanantoanina, P. Ramos, W. Ravenek, J.I. Rodríguez, P. Ros, R. Rüger, P.R.T. Schipper, D. Schlüns, H. van Schoot, G. Schreckenbach, J.S. Seldenthuis, M. Seth, J.G. Snijders, M. Solà, M. Stener, M. Swart, D. Swerhone, V. Tognetti, G. te Velde, P. Vernooijs, L. Versluis, L. Visscher, O. Visser, F. Wang, T.A. Wesolowski, E.M. van Wezenbeek, G. Wiesenekker, S.K. Wolff, T.K. Woo, A.L. Yakovlev. ADF2018; SCM ADF2018: Vrije Universiteit, Amsterdam, 2018.

(17) Klamt, A.; Schüürmann, G. COSMO: a new approach to dielectric screening in solvents with explicit expressions for the screening energy and its gradient. J. Chem. Soc., Perkin Trans. 2 1993, 5, 799805.

(18) Klamt, A. COSMO-RS: From quantum chemistry to fluid phase thermodynamics and drug design; Elsevier: Amsterdam, Oxford, 2005.

(19) OriginPro 8G SR2; OriginLab Corporation: Northampton. 
(20) Sun, L.; Campbell, M. G.; Dincă, M. Electrically Conductive Porous Metal-Organic Frameworks. Angew. Chem. Int. Ed. 2016, 55, 3566-3579.

(21) Kortüm, G. Reflexionsspektroskopie: Grundlagen, Methodik, Anwendungen; Springer: Berlin, 1969.

(22) Viezbicke, B. D.; Patel, S.; Davis, B. E.; Birnie, D. P. Evaluation of the Tauc method for optical absorption edge determination: $\mathrm{ZnO}$ thin films as a model system. Phys. Status Solidi B 2015, 252, 1700-1710.

(23) Tauc, J. Absorption edge and internal electric fields in amorphous semiconductors. Mater. Res. Bull. 1970, 5, 721-729.

(24) Davis, E. A.; Mott, N. F. Conduction in non-crystalline systems V. Conductivity, optical absorption and photoconductivity in amorphous semiconductors. Philos. Mag. 1970, 22, 903-922.

(25) Mott, N. F.; Davis, E. A. Electronic processes in non-crystalline materials, Second edition; The international series of monographs on physics; Oxford University Press: Oxford, 2012.

(26) Blum, V.; Gehrke, R.; Hanke, F.; Havu, P.; Havu, V.; Ren, X.; Reuter, K.; Scheffler, M. Ab initio molecular simulations with numeric atom-centered orbitals. Comput. Phys. Commun. 2009, 180, 2175-2196. 